December 2020

\title{
A Comprehensive Framework for Conflict Preemption in Federal Insolvency Proceedings
}

Robert W. Miller

Manier \& Herod, P.C.

Follow this and additional works at: https://researchrepository.wvu.edu/wvlr

Part of the Bankruptcy Law Commons

\section{Recommended Citation}

Robert W. Miller, A Comprehensive Framework for Conflict Preemption in Federal Insolvency Proceedings, 123 W. Va. L. Rev. 423 (2020).

Available at: https://researchrepository.wvu.edu/wvlr/vol123/iss2/5

This Article is brought to you for free and open access by the WVU College of Law at The Research Repository @ WVU. It has been accepted for inclusion in West Virginia Law Review by an authorized editor of The Research Repository@WVU. For more information, please contact ian.harmon@mail.wvu.edu. 


\title{
A COMPREHENSIVE FRAMEWORK FOR CONFLICT PREEMPTION IN FEDERAL INSOLVENCY PROCEEDINGS
}

\author{
Robert W. Miller*
}

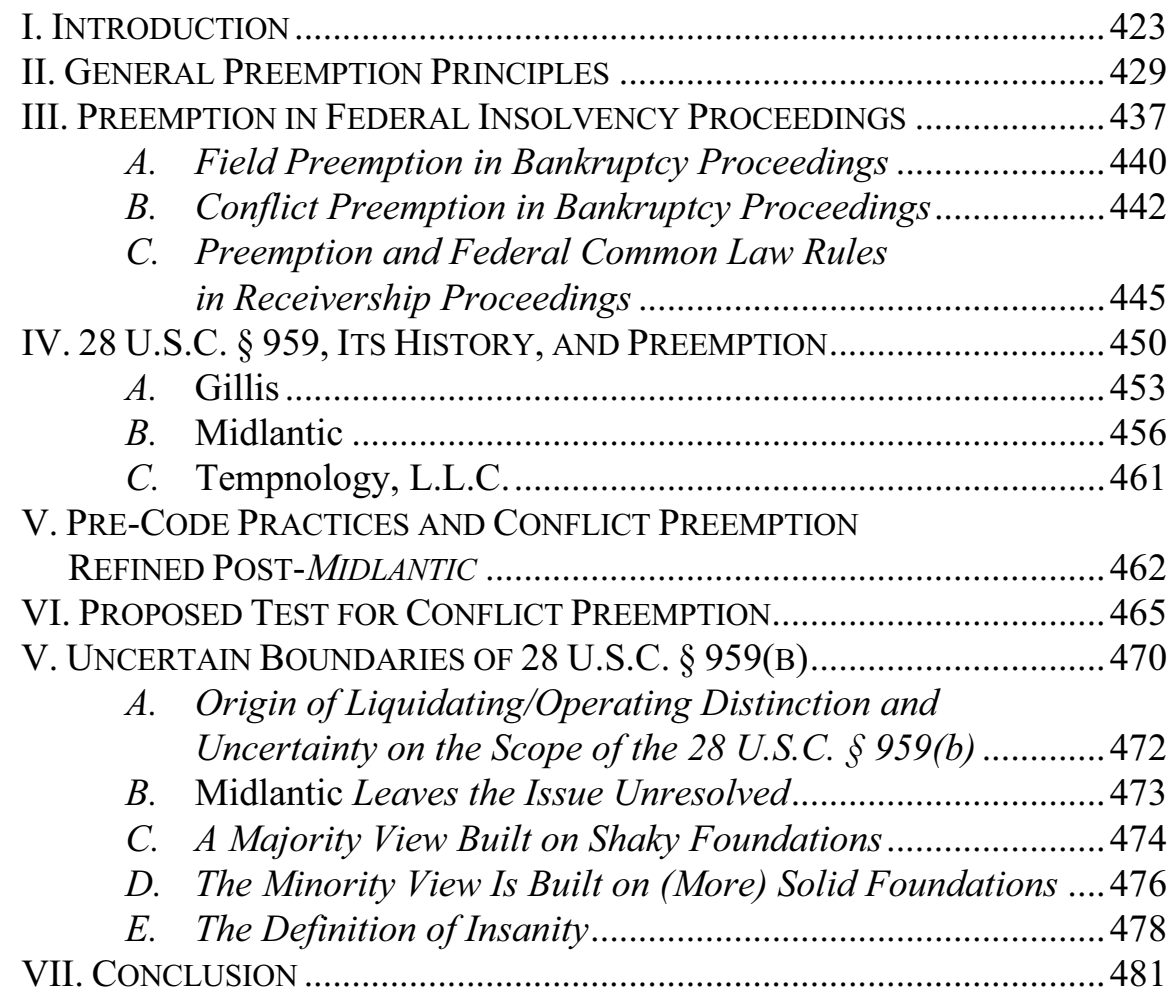

\section{INTRODUCTION}

Federal and state laws must coexist for federal insolvency regimes to function. Federal insolvency laws' primary status as a procedural overlay on substantive state-law rights establishes the foundation for this relationship; state

* $\quad$ Partner, Manier \& Herod, P.C. The Author would like to thank the many individuals who have read this article and provided feedback including my wife Alexandra E. Dugan, Christopher G. Bradley, Christopher W. Frost, Thomas H. Jackson, Pamela Foohey, and Daniel I. Waxman. All errors and omissions as well as the viewpoints expressed in this Article are the Author's own. 
laws are generally unaffected by a federal insolvency proceeding. ${ }^{1}$ Federal insolvency law, however, also seeks to maximize the distributions to creditors and, in the context of bankruptcy, discharge the debts of honest debtors ${ }^{2}$ and facilitate reorganizations. ${ }^{3}$ Consider the example of a coal producer. After it files for bankruptcy, is it still required to follow state law and clean the water polluted by its operations? The natural answer is yes, of course. However, if the coal producer does not follow state law, it will be more profitable, and its creditors will benefit, thereby vindicating a federal interest. Does the analysis change when a federal statute is in direct conflict with state law? But what if following the federal law will imperil the public interest protected by the state law? Which interest should prevail is a question of preemption.

Congress has not overhauled federal insolvency law since the 1978 enactment of the current Bankruptcy Code, and receivership law has never been subject to a comprehensive revamp. That is not to say that insolvency law has stood still while companies' finances have evolved. Instead, developments have occurred through non-statutory channels and private contracting. ${ }^{4}$ Consider how blanket liens on substantially all a debtor's assets, which were once a rare occurrence and are now the norm, have altered insolvency. ${ }^{5}$ Lenders' greater control of debtors' finances manifests even before a bankruptcy is filed by

Vanston Bondholders Protective Comm. v. Green, 329 U.S. 156, 169-71 (1946) (Frankfurter, J., concurring); Marshall v. New York, 254 U.S. 380, 385 (1920) (“"A] receiver appointed by a federal court takes property subject to all liens, priorities, or privileges existing or accruing under the laws of the state.”); Javitch v. First Union Sec., Inc., 315 F.3d 619, 625 (6th Cir. 2003) ("The general rule is that a receiver acquires no greater rights in property than the debtor had ....").

2 See Segal v. Rochelle, 382 U.S. 375, 379 (1966) (noting dual policies of bankruptcy law as providing a fresh start and maximizing distributions to creditors); Scholes v. Lehmann, 56 F.3d 750, 755 (7th Cir. 1995) (only purpose of receiver is to maximize distributions to creditors); $c f$. Desmond v. Green (In re Green), No. 13-10204, 2018 WL 4944988, at *5 (Bankr. D. Mass. Oct. $11,2018)$ ("[W]hile state law creates property rights, federal law can modify those rights for federal purposes." (citing Hunter v. Citifinancial, Inc. (In re Hunter), 284 B.R. 806, 813 (Bankr. E.D. Va. 2002))).

3 Mission Prod. Holdings, Inc. v. Tempnology, L.L.C., 139 S. Ct. 1652, 1665 (2019). "The Code also accommodates the interests of the States in regulating property transfers by "generally [leaving] the determination of property rights in the assets of a bankrupt's estate to state law." Fla. Dep't of Revenue v. Piccadilly Cafeterias, Inc., 554 U.S. 33, 51 (2008) (internal quotations omitted). Indeed, as the Supreme Court has suggested, these varying "interests often do not coincide." Id.

4 David A. Skeel, Jr. \& George Triantis, Bankruptcy's Uneasy Shift to a Contract Paradigm, 166 U. PA. L. REV. 1777, 1779 (2018) ("The most dramatic development in the decades since [the Bankruptcy Code was enacted] has been the increasing use of actual contracts to shape the bankruptcy process.").

$5 \quad$ See Ralph Brubaker, The Post-RadLAX Ghosts of Pacific Lumber and Philly News (Part I): Is Reorganization Surplus Subject to a Secured Creditor's Pre-Petition Lien?, 34 BANKR. L. LETTER, June 2014, at 1. 
determining the trajectory of the case $^{6}$ through restructuring support agreements. ${ }^{7}$ It is further exacerbated by post-petition financing orders that often eliminate mandatory protections established by the Bankruptcy Code itself. ${ }^{8}$ Many have bemoaned these developments, but Congress has failed to act. Stepping in to fill the void, commentators, including Professors Melissa B. Jacoby, Edward J. Janger, and Adam J. Levitin, have posed procedural responses that fulfill congressional intent. ${ }^{9}$

New and differing regulatory burdens mirror the shifts in debtor's financing, albeit with the same congressional response. State regulations, like environmental safeguards and consumer protections, will likely continue to proliferate ensuring that conflicts between federal insolvency law and state law become more common. ${ }^{10}$ With only limited express and field preemption

$6 \quad$ See Diane Lourdes Dick, The Bearish Bankruptcy, 52 GA. L. REv. 437, 482 (2018) (describing how milestones created pursuant to debtor-in-possession financing set case timelines that are advantageous to the debtor's post-petition lender).

Douglas G. Baird, Bankruptcy's Quiet Revolution, 91 AM. BANKR. L.J. 593, 603 (2017) (" $[\mathrm{S}]$ ecured creditors have ... discovered that they could increase their control over the debtor ... through the use of restructuring support agreements."); Edward J. Janger \& Adam J. Levitin, Badges of Opportunism: Principles for Policing Restructuring Support Agreements, 13 BROOK. J. CORP. FIN. \& COM. L. 169 (2018) (explaining that even though restructuring support agreements can serve a salutary purpose as a "bridge" between expedited 363 sales and the slower plan of reorganization process, they also can facilitate rent seeking by secured creditors); Skeel, Jr. \& Triantis, supra note 4, at '1807 (describing restructuring support agreements and their impact on secured creditors' control of the case through the use of milestones); cf. David A. Skeel, Jr., Creditors' Ball: The "New" New Corporate Governance in Chapter 11, 152 U. PA. L. REv. 917, 929, 935-39 (2003) (explaining how linking milestones with executive compensation, particularly bonuses, provides lenders with even greater control).

$8 \quad$ Sally McDonald Henry, Paying-To-Play in Chapter 11, 17 J. Bus. \& SEC. L. 113, 121 (2016) (discussing secured creditors frequent success in extracting concessions from debtors in the context of debtor-in-possession financing including waiver surcharge rights in 11 U.S.C. $\S 506(\mathrm{c})$ and the "equities of the case" exception in 11 U.S.C. $\$ 552$ to perfection in proceeds of collateral created post-petition); see also Skeel, Jr. \& Triantis, supra note 4, at '1781 (“'B] ankruptcy practice has taken contracting even further, permitting parties also to contract around [Bankruptcy Code] provisions whose language is not permissive.").

9 Melissa B. Jacoby \& Edward J. Janger, Ice Cube Bonds: Allocating the Price of Process in Chapter 11 Bankruptcy, 123 YALE L.J. 862, 865-66 (2014) (suggesting the use of extrastatutory protection of "ice cube bonds" to counterbalance the need for a quick sale of the debtor's assets under $\S 363$ of the Bankruptcy Code based on the assets' status as a "melting ice cube"); Janger \& Levitin, supra note 7, at 169 (explaining how the Bankruptcy Code limits situational leverage but noting how end-runs have been successful in mitigating the limitations and noting the need for specific analyses of these end-runs to return the rebalance the leverage instated by the Bankruptcy Code).

10 That is not to say that state regulations have not traditionally impacted insolvency proceedings. Melvin G. Shimm, The Impact of State Law on Bankruptcy, 1971 DukE L.J. 879, 891 (noting that in New York, regulation is so extensive that federal insolvency proceedings have become "in practice - if not strictly in law — a state bankruptcy proceeding."). 
applicable in federal insolvency proceedings, ${ }^{11}$ conflict preemption takes on an outsized importance. This significance does not translate to ease of analysis because no coherent framework for evaluating conflict preemption has ever existed. ${ }^{12}$ Neither Congress nor the Supreme Court of the United States has integrated the various strands of authority and precedent into an assessment tool. Left without guidance, lower courts have identified some useful overarching principles but have failed to establish a comprehensive test. ${ }^{13}$ Only recently, in cases as divergent as coal producer Cloud Peak Energy Inc. ${ }^{14}$ and for-profit education provider ITT Educational Services, Inc. ${ }^{15}$ have conflict preemption issues arisen without a comprehensive framework for their evaluation.

This Article conforms the three principal sources of authority: (i) the preCode practice doctrine, (ii) 28 U.S.C. $§ 959$ (b) - the federal insolvency saving clause, and (iii) the Supreme Court's holdings in Gillis v. California ${ }^{16}$ and Midlantic National Bank v. New Jersey Department of Environmental Protection $^{17}$ to create a comprehensive framework for evaluating conflict preemption issues in federal insolvency proceedings:

(I) When 28 U.S.C. $§ 959(b)$ is not triggered:

a. In bankruptcy or a receivership governed by bankruptcy law, the traditional conflict preemption analysis applies, ${ }^{18}$ unless a historical practice exists

\footnotetext{
11 See generally Oleksandra Johnson, The Bankruptcy Code as Complete Preemption: The Ultimate Trump?, 81 Am. BANKR. L.J. 31 (2007).

12 See, e.g., BFP v. Resol. Tr. Corp., 511 U.S. 531, 540-43 (1994); Kelly v. Robinson, 479 U.S. 36, 44-47 (1986); Midlantic Nat'l Bank v. N.J. Dep't of Env't Prot., 474 U.S. 494, 501 (1986); Perez v. Campbell, 402 U.S. 637 (1971).

13 See Baker \& Drake, Inc. v. Pub. Serv. Comm'n of Nev. (In re Baker \& Drake, Inc.), 35 F.3d 1348, 1353 (9th Cir. 1994) (noting that "federal bankruptcy preemption is more likely . . where a state statute is concerned with economic regulation rather than with protecting public health and safety"); Pub. Serv. Co. of N.H. v. New Hampshire (In re Pub. Serv. Co. of N.H.), 108 B.R. 854, 870 (Bankr. D.N.H. 1989) (noting that while "state police power enforcement of issues dealing with imminent threats to public health and safety are accorded overriding importance notwithstanding bankruptcy proceedings," nonetheless "federal pre-emption is more likely when the state police power involved is economic regulation rather than health or safety").

14 See Objection of Arch Insurance Company filed May 28, 2019, In re Cloud Peak Energy, Inc., Case No. 19-11047 (Bankr. D. Del.).

15 See Post-Hearing Brief for Creditors filed June 5, 2017, In re ITT Educ. Servs. Inc., Case No. 16-07207 (Bankr. S.D. Ind.).

16293 U.S. 62 (1934).

$17 \quad 474$ U.S. 494 (1986).

18 Hillsborough Cnty. v. Automated Med. Lab’ys, Inc., 471 U.S. 707, 713 (1985).
} 
excepting the conflicting state law from preemption; ${ }^{19}$ or

b. In a non-bankruptcy law governed receivership, the traditional determination of whether a uniform federal common law governs unless a historical practice incorporating state law applies.

(II) When 28 U.S.C. $\S 959$ (b) is triggered, a state law governing the management or operation of property

a. is not preempted or is incorporated as the federal common law rule when the property is being managed or operated

(i) in the ordinary course,$^{20}$ or

(ii) pursuant to 11 U.S.C. $\S 363$ (b) or an equivalent receivership law or rule. ${ }^{21}$

b. is preempted or a uniform federal common law rule applies when an insolvency law or federal interest precisely delimits operation or management, ${ }^{22}$ unless

(i) a historical practice exists to support excepting the state law from conflict preemption or a uniform federal common law rule, ${ }^{23}$

(ii) the state law is "reasonably designed to protect the public health or safety from identified hazards"; and

(iii) an "imminent and identifiable harm" exists. ${ }^{24}$

A set of brief hypotheticals (to which we will return) illustrates how this test is applied. First, if an Estate Representative is operating as a landlord debtor, must the Estate Representative abide by the applicable rent controls (or reclaim the land in the coal mining example)? Obviously, yes: 28 U.S.C. $§ 959$ (b) requires the Estate Representative to follow state law, and nothing in insolvency

19 See BFP v. Resol. Tr. Corp., 511 U.S. 531, 540-43 (1994); Kelly v. Robinson, 479 U.S. 36, 44-47 (1986).

20 Gillis v. California, 293 U.S. 62, 65 (1934); Ky. Emps. Ret. Sys. v. Seven Cntys. Servs., Inc., 823 F. App'x 300, 305 (6th Cir. 2020).

21 E.g., Calvert v. Bongards Creameries (In re Schauer), 835 F.2d 1222, 1225 (8th Cir. 1987).

22 Midlantic Nat'l Bank, 474 U.S. at 501.

23 This intent usually takes the form of the pre-Code Practices Doctrine but can also be signaled by federal legislation reflecting similar priorities to the relevant state legislation.

24 Midlantic Nat'l Bank, 474 U.S. at 506-07, 507 n.9. 
law's mostly procedural framework suggests otherwise. ${ }^{25}$ Next, can an Estate Representative conduct a store closing sale in contravention of state going-outof-business regulations? No, state law is incorporated as the rule of decision, and it precludes the sale. Turning to the tougher examples, can a debtor reject an unexpired lease for an auto dealership in contravention of state laws imposing notice requirements and requiring the debtor repurchase inventory? ${ }^{26} \mathrm{Yes}$, if a federal statute is in direct conflict with the state law which does not implicate an imminent risk to public health and safety. Lastly, can a debtor reject an unexpired lease for polluted property, leaving the state and the lessor to remediate the property and bear the associated costs? Maybe, depending upon whether the harm is imminent and identifiable as well as whether a historical pre-Code practice exists limiting preemption. ${ }^{27}$ By replacing an uncertain array of factors with a comprehensive evaluation tool, the focus can shift from determining how conflict preemption should be evaluated to making the evaluation itself. The result: lower litigation costs, more predictable results, and greater judicial economy.

The test proposed by this Article requires surmounting two hurdles: (i) ascertaining 28 U.S.C. § 959(b)'s effect on obstacle preemption and (ii) resolving the circuit split over the application of 28 U.S.C. § 959(b).

This Article is the first commentary to identify 28 U.S.C. $§ 959(b)$ 's status as a specific saving clause and its elimination of obstacle preemption when it is triggered in a federal insolvency proceeding. ${ }^{28}$ Professor Laurence H. Tribe first suggested, and the Supreme Court later confirmed, albeit vaguely, the disparate impact of general and specific saving clauses on conflict preemption. ${ }^{29}$ Yet, scholars have struggled to find an example of a specific saving clause and pin down the impact of such a clause on the relevant preemption analysis. ${ }^{30}$ Indeed, this Article may be the first to pinpoint an example of a specific saving clause and confirm its elimination of obstacle preemption. Acknowledging this status establishes a platform for conforming 28 U.S.C. § 959(b) with the other two sources of authority and creating a framework for a comprehensive test to analyze conflict preemption in federal insolvency proceedings. 
This Article provides conclusive evidence that settles the debate over the scope of 28 U.S.C. $§ 959$ (b). The majority of published opinions only apply 28 U.S.C. $\S 959($ b) to operating Estate Representatives while leaving their liquidating counterparts unrestricted. ${ }^{31}$ Instead of merely poking holes in the reasoning underlying the split, this Article definitively explains why 28 U.S.C. § 959(b) applies equally to liquidating and non-liquidating Estate Representatives. The most damning, yet previously overlooked, evidence against this artificial distinction derives from lower courts having already made the same mistake analyzing its sister statute, 28 U.S.C. $§ 960 .{ }^{32}$ Paralleling the current split, many courts drew the same distinction between liquidating and operating Estate Representatives based on the same plain language and policy arguments. ${ }^{33}$ The Supreme Court resolved this split in California State Board of Equalization v. Sierra Summit, Inc., ${ }^{34}$ where it held that 28 U.S.C. $\S 960$ applies equally to liquidating and operating Estate Representatives. ${ }^{35}$ The same reasoning and conclusion resolve the circuit split over 28 U.S.C. § 959(b).

To set the stage for this Article, Part II provides a brief overview of preemption. Part III then illustrates how these principles have been applied to conflicts between federal insolvency law and state law. Next, Part IV summarizes the history of 28 U.S.C. $\S 959$ (b) and explains why it is a specific saving clause as well as the implications of this designation. Part V describes the pre-Code practice exception and evaluates its impact on conflict preemption in federal insolvency proceedings. Part VI, the centerpiece of the article, proposes a comprehensive test for conflict preemption in federal insolvency proceedings. Lastly, Part VII explains why 28 U.S.C. § 959(b) applies equally to liquidating and operating Estate Representatives.

\section{GENERAL PREEMPTION PRINCIPLES}

The tension between state and federal law is inherent to the United States' federal system of government. When state and federal laws collide, the

\footnotetext{
31 See, e.g., In re Corona Plastics, Inc., 99 B.R. 231, 236 (Bankr. D.N.J. 1989).

32 See, e.g., Blackmon v. Nichols (In re Hatfield Const. Co.), 494 F.2d 1179, 1181 (5th Cir. 1974); In re Samoset Assocs., 14 B.R. 408, 414 (Bankr. D. Me. 1981).

33 Compare Great Am. Bank of Broward Cnty. v. McCracken (In re Cusato Bros. Int'1, Inc.), 750 F.2d 887, 891 (11th Cir. 1985) (exempting liquidating trustee); Cal. State Bd. of Equalization v. Goggin, 245 F.2d 44 (9th Cir.), cert. denied, 353 U.S. 961 (1957) (same), and In re Samoset Assocs., 14 B.R. at 414 (same), with Blackmon, 494 F.2d at 1181 (liquidating trustee must pay applicable taxes), and Missouri v. Gleick, 135 F.2d 134, 137 (8th Cir. 1943) (same).

34 Cal. State Bd. of Equalization v. Sierra Summit Inc., 490 U.S. 844 (1989).

$35 \quad$ Id. at 854.
} 
Supremacy Clause of the Constitution ensures the triumph of federal law. ${ }^{36}$ That said, preemption of state law is disfavored. ${ }^{37}$ An actual contradiction between federal law and state law is required to trigger preemption. ${ }^{38}$

The nomenclature of preemption is well established. Preemption is divided into two types: express preemption and implied preemption. ${ }^{39}$ Implied preemption is subdivided into field preemption and conflict preemption while conflict preemption, the topic of this Article, is further bifurcated into an impossibility branch and an obstacle branch. ${ }^{40}$ Irrespective of the type of preemption at issue, express or implied, field or conflict, congressional intent to preempt state law is the keystone to the analysis: ${ }^{41}$ Did Congress intend federal or state law to govern?

Express preemption arises when the language of a statute directs federal law's displacement of state law. ${ }^{42}$ Courts evaluating whether an express preemption provision is applicable use a two-part test: (i) determine whether the clause intends to preempt state law and (ii) then determine "whether the Constitution permits Congress to bar the states from exercising the powers in

36 U.S. CONST. art. IV, § 2; Ware v. Hylton, 3 U.S. (3 Dall.) 199, 204 (1796); Morgan v. Ford Motor Co., 680 S.E.2d 77, 83 (W. Va. 2009) ("Preemption of topics traditionally regulated by states - like health and safety - is greatly disfavored in the absence of convincing evidence that Congress intended for a federal law to displace a state law.").

37 Consol. Edison v. Montana, 453 U.S. 609, 634 (1981).

38 Stellwagen v. Clum, 245 U.S. 605, 613 (1918).

39 The taxonomy of preemption, which merits description due to its common usage, suffers from multiple problems that are beyond the direct scope of this paper. See Caleb Nelson, Preemption, 86 VA. L. ReV. 225, 262-64 (2000) [hereinafter Nelson, Preemption].

40 The Ninth Circuit has concluded that a fourth type of preemption can be applicable in bankruptcy proceedings: complete preemption. See Miles v. Okun (In re Miles), 430 F.3d 1083, 1086 (9th Cir. 2005); MSR Expl., Ltd. v. Meridian Oil, Inc., 74 F.3d 910 (9th Cir. 1996). Complete preemption is not equivalent to field preemption. Rosenberg v. DVI Receivables SVII, L.L.C., 835 F.3d 414, 421 n.4 (3d Cir. 2016). Complete preemption "operates to confer original federal subject matter jurisdiction notwithstanding the absence of a federal cause of action on the face of the complaint." In re U.S. Healthcare, Inc., 193 F.3d 151, 160 (3d Cir. 1999). It only applies when the preemptive force of a federal statute is so "extraordinary" that it "converts an ordinary state common-law complaint into one stating a federal claim for purposes of the well-pleaded complaint rule." Caterpillar Inc. v. Williams, 482 U.S. 386, 393 (1987). The Supreme Court has only recognized complete preemption in three contexts, none of which are bankruptcy. Rosenberg, 835 F.3d at 421 n.4; accord Robinson v. Mich. Consol. Gas Co. Inc., 918 F.2d 579, 585 (6th Cir. 1990). The Ninth Circuit stands alone among the circuits in recognizing it in the bankruptcy context. Miles, 430 F.3d at 1086; MSR Expl., Ltd., 74 F.3d at 910.

41 See Cipollone v. Liggett Grp., Inc., 505 U.S. 504, 516 (1992) (“Congress' intent may be "explicitly stated in the statute's language or implicitly contained in its structure and purpose." (quoting Jones v. Rath Packing Co., 430 U.S. 519, 525 (1977))).

42 Hillsborough Cnty. v. Automated Med. Lab'ys, 471 U.S. 707, 713 (1985); Pac. Gas \& Elec. Co. v. State Energy Res. Conservation \& Dev. Comm'n, 461 U.S. 190, 203 (1983) ("It is wellestablished that within Constitutional limits Congress may preempt state authority by so stating in express terms."). 
question. ${ }^{" 43}$ Congress's decision to employ express preemption also affects the applicability of implied preemption. The use of a broad express preemption clause supports an inference of congressional intent to exclude implied preemption. $^{44}$

Even without Congress enacting an express preemption clause, implied preemption may displace state law. Implied preemption's split between field and conflict preemption reflects the distinction between substantive rules and jurisdictional rules. ${ }^{45}$ Substantive rules typically "regulate conduct directly, while jurisdictional rules tend to say that states may not regulate certain areas of conduct (or at least may not do so in particular ways). ${ }^{, 46}$

Field preemption arises when federal legislation directly regulates a subject area (thereby providing a substantive rule) so pervasively that no room exists for state law to supplement or provide an alternative. ${ }^{47}$ When a court recognizes field preemption, it is inferring an express preemption clause even though Congress failed to enact one ${ }^{48}$ However, without any guidance, the court still must make the uncomfortable determination of the scope of the "field" to be preempted as well as Congress's power to preempt state law in the applicable "field." 50 So there is little wonder that courts are often cautious to apply field preemption without a firm textual basis. ${ }^{51}$

When state laws violate jurisdictional rules by undermining federal law through the overlap between state and federal law, conflict preemption occurs. More specifically, conflict preemption arises when it is impossible to comply with both a state law and a federal law or "where state law erects an obstacle to the accomplishment and execution of the full purposes and objectives of

\footnotetext{
$43 \quad$ Nelson, Preemption, supra note 39, at 227.

$44 \quad$ Freightliner Corp. v. Myrick, 514 U.S. 280, 289 (1995).

45 Nelson, Preemption, supra note 39, at 262.

$46 \quad$ Id. at 261.

47 Gade v. Nat'l Solid Wastes Mgmt. Ass'n, 505 U.S. 88, 98 (1992); Sikkelee v. Precision Airmotive Corp., 822 F.3d 680, 687-88 (3d Cir. 2016) (holding that for the doctrine of field preemption to apply, a court "must find that federal law leaves no room for state regulation and that Congress had a clear and manifest intent to supersede state law" in that field); Blue Cross of Cal. v. Anesthesia Care Assocs. Med. Grp., Inc., 187 F.3d 1045, 1054 (9th Cir. 1999).

$48 \quad$ Nelson, Preemption, supra note 39, at 227.

49 Abdullah v. Am. Airlines, Inc., 181 F.3d 363, 367 (3d Cir. 1999) (“[A]lthough the term field preemption suggests a broad scope, the scope of a field deemed preempted by federal law may be narrowly defined." (internal citations omitted)).

$50 \quad$ Nelson, Preemption, supra note 39, at 227.

51 See Camps Newfound/Owatonna, Inc. v. Town of Harrison, 520 U.S. 564, 616-17 (1997) (Thomas, J., dissenting) ("Furthermore, field pre-emption is itself suspect, at least as applied in the absence of a congressional command that a particular field be pre-empted. Perhaps recognizing this problem, our recent cases have frequently rejected field pre-emption in the absence of statutory language expressly requiring it.").
} 
Congress." $" 52$ These two types of conflict preemption are labeled the "impossibility branch" and the "obstacle branch." 53

A state law triggers the impossibility branch when it is physically impossible for a litigant to comply with both the federal law and state law. ${ }^{54}$ This branch has been interpreted very narrowly. It is evaluated not only on the dimension of action but also inaction, and compliance on either dimension is sufficient to forestall physical impossibility. ${ }^{55}$ Even when state and federal law contradict each other by requiring different actions, a party's ability to decline to act at all saves the state law from preemption. ${ }^{56}$ As a result, physical impossibility only arises in "a case in which state law penalizes what federal law requires or when state law claims directly conflict with federal law."

In contrast to the narrowness of the impossibility branch, the obstacle branch can be applied very broadly to preempt "not only cases in which state and federal law contradict each other, but also all other cases in which courts think that the effects of state law will hinder accomplishment of the purposes behind federal law." ${ }^{" 58}$ Originally, the subjective intent of a state legislature could immunize a statute from the obstacle branch. ${ }^{59} \mathrm{~A}$ state statute would not be preempted even when it frustrated a federal statute, so long as the state statute was not enacted to purposefully obstruct the federal statute. ${ }^{60}$ State legislatures could easily game the analysis. ${ }^{61}$ Recognizing this issue, the Supreme Court pivoted to an objective focus: "whether a challenged state statute 'stands as an obstacle to the accomplishment and execution of the full purposes and objectives 52 Hillsborough Cnty. v. Automated Med. Lab’ys, 471 U.S. 707, 713 (1985).
$53 \quad$ In re Methyl Tertiary Butyl Ether (MTBE) Prod. Liab. Litig., 725 F.3d 65, 97, 101 (2d Cir.
2013 ).
$54 \quad$ Fid. Fed. Sav. \& Loan Ass'n v. de la Cuesta, 458 U.S. 141, 153 (1982); Fla. Lime \& Avocado Growers, Inc. v. Paul, 373 U.S. 132, 142-43 (1963).

55 Wyeth v. Levine, 555 U.S. 555, 589-90 (2009) (Thomas, J., concurring) (discussing that the usual impossibility analysis may be too narrow).

$56 I d$. at 590 (citing Nelson, Preemption, supra note 39, at 260-61).

57 Geier v. Am. Honda Motor Co., Inc., 529 U.S. 861, 873 (2000).

58 Nelson, Preemption, supra note 39, at 228-29; see also In re Physiotherapy Holdings, Inc., No. 13-12965(KG), 2016 WL 3611831, at *6 (Bankr. D. Del. June 20, 2016) ("With respect to the obstacle branch, the court noted that a finding of conflict preemption was appropriate where state law stands as an obstacle to the accomplishment and execution of the full purposes and objectives of Congress." (internal citations omitted)).

59 A bankruptcy case confirmed the validity and general applicability of the obstacle branch. Perez v. Campbell, 402 U.S. 637, 651-52 (1971) (abrogating Kesler v. Dep’t of Pub. Safety, 369 U.S. 153 (1962), and Reitz v. Mealey, 314 U.S. 33 (1941)).

$60 \quad$ Id. at $651-52$.

$61 \quad I d$. at 652 ("[S] uch a doctrine would enable state legislatures to nullify nearly all unwanted federal legislation by simply publishing a legislative committee report articulating some state interest or policy - other than frustration of the federal objective - that would be tangentially furthered by the proposed state law."). 
of Congress." "62 Thus, the test for conflict preemption under the obstacle branch has two steps: (i) first construe the federal statute to determine its purpose and (ii) then determine whether a conflict exists between the federal purpose and state law. ${ }^{63}$

Preemption based on the obstacle branch is less likely when a federal statute is enacted in a sphere historically governed by state law. ${ }^{64}$ The policy bases for this adverse presumption are two-fold. First, it respects the traditional roles of states in governing their affairs. ${ }^{65}$ Second, the existence of a traditionally conflicting state law gives Congress the knowledge and incentive to more explicitly express its intent to preempt the state law. ${ }^{66}$ Justice Felix Frankfurter perhaps put it best in one of his scholarly writings. The relevant passage, although lengthy, is the genesis for the pre-Code practice doctrine and its application to the conflict preemption analysis in bankruptcy. As a result, it is worthy of reproduction in full.

The task is one of accommodation as between assertions of new federal authority and historic functions of the individual states. Federal legislation of this character cannot therefore be construed without regard to the implications of our dual system of government.... The underlying assumptions of our dual form of government, and the consequent presuppositions of legislative draftsmanship which are expressive of our history and habits, cut across what might otherwise be the implied range of legislation. The history of congressional legislation... justif[ies] the generalization that, when the Federal Government takes over such local radiations in the vast network of our national economic enterprise and thereby radically readjusts the balance of state and national authority, those charged with the duty of legislating are reasonably explicit. ${ }^{67}$

\footnotetext{
$62 I d$. at 637 (quoting Hines v. Davidowitz, 312 U.S. 52, 67 (1941)).

$63 \quad$ Id. at 644.

64 Rice v. Santa Fe Elevator Corp., 331 U.S. 218, 230 (1947).

65 The analysis includes "due regard for the presuppositions of our embracing federal system, including the principle of diffusion of power not as a matter of doctrinaire localism but as a promoter of democracy." San Diego Bldg. Trades Council v. Garmon, 359 U.S. 236, 243 (1959).

$66 \quad$ United States v. Texas, 507 U.S. 529, 534 (1993).

67 Felix Frankfurter, Some Reflections on the Reading of Statutes, 47 COLUM. L. REv. 527, 539-40 (1947).
} 
Applying these principles, the Supreme Court has elevated the usual standard for the obstacle branch by requiring that "congressional intent to supersede state laws must be clear and manifest." $" 68$

Because common law causes of action and state law usually predate federal regulation, Congress can decide how much of existing law it wants to preempt. As part of this balancing act, Congress may enact a "saving clause" to preserve state-law causes of action that might otherwise be preempted. ${ }^{69}$ Three types of saving clauses exist: (i) anti-preemption clauses, (ii) compliance saving clauses, and (iii) remedies saving clauses. ${ }^{70}$ An anti-preemption clause allows a state law to also operate alongside a federal statute. ${ }^{71}$ A compliance saving clause requires satisfaction of state law notwithstanding compliance with federal law (whichever is more stringent, state or federal, sets the floor for compliance).$^{72} \mathrm{~A}$ remedies saving clause preserves state law remedies. ${ }^{73}$ Regardless of the classification, most saving clauses are not sui generis as Congress often uses boilerplate versions of each type. ${ }^{74}$

68 BFP v. Resol. Tr. Corp., 511 U.S. 531, 544 (1994) (quoting English v. Gen. Elec. Co., 496 U.S. 72,79 (1990)). The Supreme Court has not always been consistent on this standard and whether it applies to only field preemption or also the obstacle branch of conflict preemption. See Betsy J. Grey, Make Congress Speak Clearly: Federal Preemption of State Tort Remedies, 77 B.U. L. REV. 559, 625 (1997) (noting this lack of consistency and advocating the application as a limitation on the obstacle branch).

69 Santos v. Crown Equip. Corp., No. 08-80161, 2009 WL 1066946, at*3-4 (S.D. Fla. Apr. 21, 2009). "It provides a statement, and sometimes a mechanism, for incorporating state interests notwithstanding a statute that seeks to implement a uniform federal program." Robert L. Fischman \& Angela M. King, Savings Clauses and Trends in Natural Resources Federalism, 32 WM. \& MARY ENV'T L. \& POL'y REV. 129, 145 (2007).

70 Jay B. Sykes \& Nicole Vanatko, Cong. Rsch. Serv., R45825, Federal Preemption: A LEgAL PRIMER 13 (2019). Some commentators divided preemption clauses into (i) jurisdictional clauses that establish the bounds of federal and state jurisdiction and remedies and (ii) cooperative saving clauses that establish how federal and state law shall work together. E.g., Fischman \& King, supra note 69 , at $145-47$.

71 SyKES \& VANATKO, supra note 70.

$72 \quad I d$. at 15 .

$73 \quad I d$. at 16.

74 Anti-preemption clauses typically "contain language indicating that 'nothing in' the relevant federal statute 'may be construed to preempt or supersede' certain categories of state law, or that the relevant federal statute 'does not annul, alter, or affect' state laws 'except to the extent that those laws are inconsistent" "with the federal statute." Id. at 14. Compliance saving clauses provide that "compliance with [the federal law] does not exempt any person from liability under [non-federal] law." Id. at 15. Remedies saving clauses often provide that "'nothing in' a federal statute "shall in any way abridge or alter the remedies now existing at common law or by statute."' Id. at $14-16$. 
A saving clause is usually accompanied by an express preemption clause because the two clauses will dovetail to define the scope of preemption. ${ }^{75}$ If correctly drafted, neither the saving clause nor the express preemption clause will operate too broadly as they will circumscribe each other's reach to effectuate congressional intent. ${ }^{76}$ In contradistinction to the natural alignment between saving clauses and express preemption clauses, the uncomfortable fit between a saving clause (an express provision) and implied preemption created uncertainty. That is until the Supreme Court's opinion in Geier v. American Honda Motor Company ${ }^{77}$ In Geier, the majority explained that the particular statute at issue did not "foreclose or limit the operation of ordinary [conflict] pre-emption principles." 78 However, it left open the possibility for Congress to alter or eliminate conflict preemption when sufficient indicia of congressional intent existed. ${ }^{79}$

Geier and its progeny outlined a three-step test for evaluating the relationship among saving clauses, express preemption clauses, and implied preemption principles: "First, we ask[] whether the statute's express pre-emption provision preempt[s] the state [law]." 80 "Second [d]oes [the saving clause] foreclose or limit the operation of ordinary pre-emption principles insofar as those principles instruct us to read federal statutes as pre-empting state laws (including state common-law standards) that 'actually conflict' with the federal statutes (or related regulations)?" ${ }^{\prime 1}$ Third, if neither of the first two prongs are satisfied, apply the traditional conflict preemption analysis. ${ }^{82}$

When evaluating the second prong of the test - the relevant prong if no preemption clause applies - the Supreme Court instructed that ordinary

\footnotetext{
75 E. Travis Ramey, Congress Hatches the Egg: Justice Thomas's Textual Mandate Test for Preemption, 62 Ala. L. ReV. 1119, 1131 (2011); accord Rodriguez v. Am. Airlines, Inc., 886 F. Supp. 967, 972 (D.P.R. 1995) ("Since Congress has not enacted an express preemption clause governing airplane safety, Morale supports our conclusion that the saving clause demonstrates the Federal Aviation Act does not preempt state common law." (emphasis in original)).

76 Geier v. Am. Honda Motor Co., Inc., 529 U.S. 861, 869 (2000) (citing and analyzing Freightliner Corp. v. Myrick, 514 U.S. 280, 287 n.3 (1995) (declining to address whether the saving clause prevents a manufacturer from "us[ing] a federal safety standard to immunize itself from state common-law liability")).

77 Id.

78 Id. Justice Stephens's dissent asserted that the saving clause established a "special burden" on a party seeking to apply conflict preemption principles. Id. at 899 (Stephens, J., dissenting).

$79 \quad I d$. at 872 ("We do not claim that Congress lacks the constitutional power to write a statute that mandates [an alteration of conflict preemption principles]. But there is no reason to believe Congress has done so here.").

80 Williamson v. Mazda Motor of Am., Inc., 562 U.S. 323, 329 (2011) (citing Geier, 529 U.S. at 867$)$.

$81 \quad$ Id.

$82 \quad$ Id. at $329-30$.
} 
preemption principles apply when a "general" saving clause is implicated. ${ }^{83}$ Given the Supreme Court's use of the word "general," as well as the admission that Congress could alter conflict preemption principles, a specific saving clause should be accorded different effect. Why otherwise would this second prong even exist? If all saving clauses simply eliminated express preemption and could accomplish nothing else, then the second prong would be superfluous.

The specificity of the saving clause is an appropriate measuring stick for congressional intent, the keystone of the preemption analysis. ${ }^{84}$ Consistent with basing this analysis on specificity, when Congress enacts a general saving clause for an entire statute, or the clause is repeated in a boilerplate fashion, courts will interpret it narrowly, ${ }^{85}$ and the usual conflict preemption branches will apply. ${ }^{86}$ In contrast, when Congress tailors a saving clause to a specific type of state or common law, greater indicia of Congressional intent to preserve state law exists. ${ }^{87}$ As Professor Tribe suggested, a specific saving clause narrows an associated implied preemption analysis. ${ }^{88}$ This perspective is consistant with the Supreme Court's interpretation of specific saving clauses. A specific saving clause will only be neutered when the state law is "absolutely inconsistent with the provisions of the act. In other words, the act cannot be held to destroy itself." ${ }^{\circ 9}$ Such an analysis will retain the impossibility branch; ${ }^{90}$ the question is whether direct conflict between state law and the provisions of the federal statute exists. Meanwhile, the obstacle branch (and its focus on frustration of purpose)

\section{Geier, 529 U.S. at 873-74.}

84 M. Stuart Madden, Federal Preemption of Inconsistent State Safety Obligations, 21 PACE L. REV. 103, 157-58 (2000) (noting that specificity is the key variable when measuring congressional intent); cf. Geier, 529 U.S. at 873-74.

85 Woods v. Gen. Motors Co., 865 F.2d 395, 416 (1st Cir. 1988) (citing Int'l Paper Co. v. Ouellett, 479 U.S. 461, 494 \& n.14 (1987)).

86 Geier, 529 U.S. at 873-74 ('The Court has thus refused to read general 'saving' provisions to tolerate actual conflict both in cases involving impossibility . . . and in 'frustration-of-purpose' cases.”); Int'1 Paper Co. v. Ouellette, 479 U.S. 481, 493-96 (1987). Although both Geier and Ouellette involved both express preemption and saving clauses, their use of the term "general" saving clause means that their holdings are likely applicable when only a saving clause is at issue. 87 TRIBE, supra note 29.

88 Id.; Francis J. Facciolo \& Richard L. Stone, Avoiding the Inevitable: The Continuing Viability of State Law Claims in the Face of Primary Jurisdiction and Preemption Challenges Under the Securities Exchange Act of 1934, 1995 Colum. Bus. L. REv. 525, 549 n.69; cf. Maher, supra note 30 (suggesting that the use of greater specificity than that found in a typical preemption statute can signal Congressional intent to limit or eliminate obstacle preemption).

89 Nader v. Allegheny Airlines, Inc., 426 U.S. 290, 299 (1976) (quoting Tex. \& Pac. Ry. Co. v. Abilene Cotton Oil Co., 204 U.S. 426, 446 (1907)).

90 McCuskey, supra note 30, at 1122 (when determining the scope of implied preemption to be applied in the face of the saving clause of the Affordable Care Act, "[t]he application of straightforward impossibility preemption goes without saying, as neither an express preemption provision nor a saving clause bars the ordinary working of conflict pre-emption principles" (quoting Buckman Co. v. Plaintiffs' Legal Comm., 531 U.S. 343, 352 (2001))). 
is inapplicable. ${ }^{91}$ Otherwise, the court would fail to properly weigh Congress's greater focus on circumscribing preemption in a particular instance and the difference between specific and general saving clauses would be illusory. ${ }^{92}$

The recent scholarly analysis of the Affordable Care Act's ("ACA") saving clause is illustrative. The ACA's saving clause provides that "[n]othing in [Title I] shall be construed to preempt any State law that does not prevent the application of the provisions of this title." 93 This saving clause is best categorized as an anti-preemption clause, but Congress failed to employ the usual boilerplate anti-preemption saving clause verbiage. ${ }^{94}$ Instead of defaulting to the phrase "inconsistent with," Congress selected "prevent the application." "95 Scholars have loosely followed the framework advocated by Professor Tribe and evaluated the impact of Congress's choice of this phraseology and whether it signals an intent to limit or eliminate obstacle preemption. ${ }^{96}$

\section{PREEMPTION IN FEDERAL INSOLVENCY PROCEEDINGS}

Although Congress has the power to preempt all state laws applicable in insolvency proceedings, it has chosen to generally use federal insolvency law as only a procedural overlay on substantive underlying state law. Congress has only used express preemption sparingly in federal insolvency statutes. Similarly, courts have only found field preemption in limited instances: a debtor's discharge and the distribution of a debtor's property. Accordingly, plenty of ground exists for obstacle preemption to cover. Consistent with the status of insolvency law as procedural overlay, however, it is far from all encompassing.

Pursuant to the Bankruptcy Clause, Congress has plenary legislative power "on the subject of Bankruptcies." ${ }^{97}$ Yet, during most of the 19th century, Congress failed to enact a permanent bankruptcy statute as the 1800,1841 and 1867 statutes were either shortly repealed or not reauthorized. ${ }^{98}$ Their brief lifespans owed much to the distrust of federal courts and the perceived importance of retaining "states' rights" by narrowing federal jurisdiction. ${ }^{99}$ As a

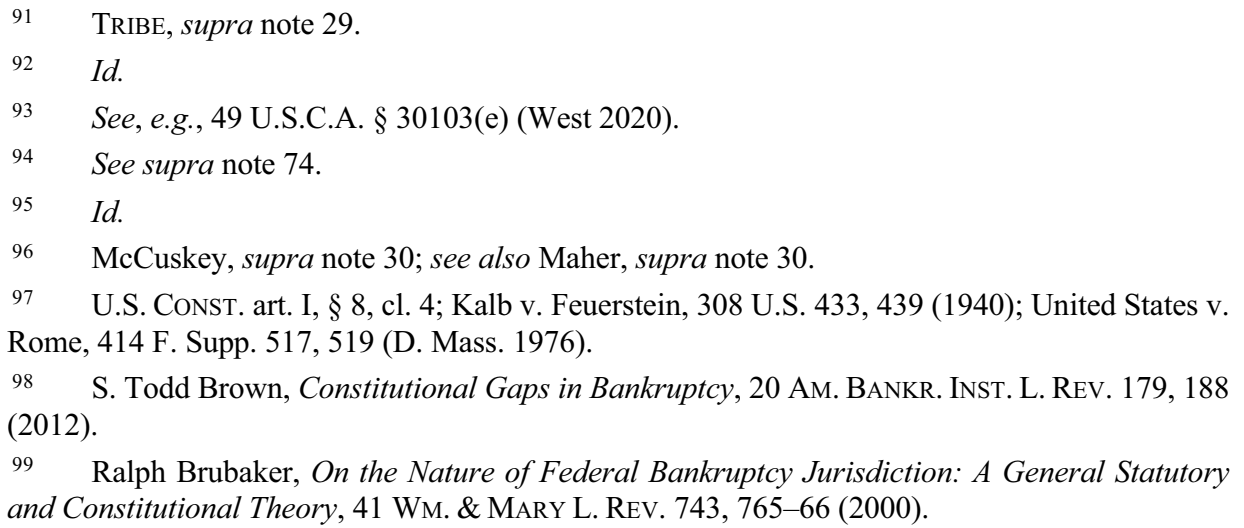


result, for most of its first century, the United States lacked a federal bankruptcy statute. ${ }^{100}$

Due to the lengthy periods when federal bankruptcy legislation was not in force, states enacted their own insolvency laws to fill these gaps. ${ }^{101}$ In the landmark case of Sturges v. Crowninshield, ${ }^{102}$ the Supreme Court recognized that these state laws, which would otherwise conflict with legislation passed pursuant to the Bankruptcy Clause, were not precluded when Congress was not exercising its power to enact uniform bankruptcy legislation. ${ }^{103}$

The enactment of permanent comprehensive bankruptcy legislation in the form of first the 1898 Bankruptcy Act, and later the Bankruptcy Code, did not expressly preempt all state law in bankruptcy proceedings. ${ }^{104}$ Congress confirmed its decision by failing to enact broad express preemption clauses in either statute. ${ }^{105}$ In the case of the Bankruptcy Code, Congress chose to individually signal express preemption by using the word "notwithstanding" coupled with a reference to applicable non-bankruptcy law. ${ }^{106}$ These provisions are few and far between. ${ }^{107}$

\footnotetext{
100 Constitutional Status of State Insolvency Laws: Preemption, CoRnell L. SCH., https://www.law.cornell.edu/constitution-conan/article-1/section-8/clause-4/constitutional-statusof-state-insolvency-laws-preemption (last visited Sept. 24, 2020). "Thus, during the first eightynine years under the Constitution, a national bankruptcy law was in existence only sixteen years altogether." Id.

101 Effect of National Bankruptcy Act on State Insolvency Statutes, 49 YALE L.J. 1090, 1090 (1940).

10217 U.S. (4 Wheat.) 122 (1819).

103 Id. at 196; see also Ogden v. Saunders, 25 U.S. (12 Wheat.) 213, 368 (1827). Even with this allowance, state insolvency laws cannot provide the same scope of relief as federal bankruptcy laws. For instance, state insolvency laws are still subject to article I, section 10, of the Contracts Clause, which precludes a state from impairing contractual obligations. In re City of Vallejo, 403 B.R. 72, 77 (Bankr. E.D. Cal. 2009), aff'd, 432 B.R. 262 (E.D. Cal. 2010) (citing Cont'l Ill. Nat'l Bank \& Tr. Co. v. Chicago, Rock Island \& Pac. Ry. Co., 294 U.S. 648, 680-81 (1935)). They also cannot apply to property extraterritorially. Brown v. Smart, 145 U.S. 454, 457 (1892); Denny v. Bennett, 128 U.S. 489, 498 (1888).

104 Brubaker, supra note 99. This failure not only confirms Congress's decision to not "occupy the entire field" of bankruptcy, it also created the basis for the "pre-Code practice" doctrine.

105 Id.

106 In re Congoleum Corp., No. 03-51524, 2008 WL 4186899, at *3-4 (Bankr. D.N.J. Sept. 2, 2008).

107 E.g., 11 U.S.C.A. $\S \S 524,525,704,1106,1123(a)(5), 1142,1202,1302$ (West 2020). Courts do not even uniformly agree that these examples expressly preempt state law. See In re Pac. Gas \& Elec. Co., 273 B.R. 795, 806 (Bankr. N.D. Cal. 2002) (Even though 11 U.S.C. § 1123(a)(5) uses the "[n]otwithstanding any otherwise applicable nonbankruptcy law a plan shall ... provide adequate means for implementation," it should not be read to allow federal bankruptcy law to preempt all applicable state law in order to implement a chapter 11 plan.).
} 
Federal court equity receiverships often functioned as the predecessors to modern reorganizations. ${ }^{108}$ They were, and currently are, subject to Congressional authority even though they are not recognized in the Constitution. ${ }^{109}$ Nonetheless, receiverships remained completely uncodified during the 19th Century. ${ }^{110}$ Even today, equity receiverships are only organized pursuant to a patchwork structure including the Federal Rules of Civil Procedure and the Judicial Code. ${ }^{111}$ This "loose scheme" provides for neither a detailed system for administering federal equity receiverships ${ }^{112}$ nor any basis for express preemption.

Congress's restraint is sensible given that federal insolvency law is a procedural overlay on substantive state or federal law. ${ }^{113}$ The Bankruptcy Clause authorizes Congress to enact laws affecting or invalidating property rights. ${ }^{114}$ Yet, as the Supreme Court famously explained in Butner v. United States, ${ }^{115}$ "Congress has generally left the determination of property rights in the assets of a bankrupt's estate to state law." 116 This is equally true in receivership

\footnotetext{
108 Janvey v. Alguire, No. 3:09-CV-0724-N, 2014 WL 12654910, at *14 (N.D. Tex. July 30, 2014), aff'd, 847 F.3d 231 (5th Cir. 2017).

109 Gillis v. California, 293 U.S. 62, 65 (1934).

110 Link v. Powell, 57 F.2d 591, 592 (W.D.S.C. 1932). The codification began in 1911. See id. ("The statute under which the receivers were appointed was enacted on March 3, 1911, 36 Stat. 1102, Judicial Code, $\S 56,28$ U.S.C. $§ 117 . ”)$. For a discussion of equity receiverships and their relationship to modern reorganization proceedings, consider Charles Jordan Tabb, The History of the Bankruptcy Laws in the United States, 3 Am. Bankr. Inst. L. ReV. 5, 21-23 (1995).

111 Janvey, 2014 WL 12654910, at*14.

112 It is unsurprising that "the district court has broad powers and wide discretion to determine the appropriate relief in an equity receivership.” Sec. \& Exch. Comm'n v. Lincoln Thrift Ass'n, 577 F.2d 600, 606 (9th Cir. 1978). These powers are much broader than those available to a bankruptcy judge under 11 U.S.C. § 105(a). See, e.g., Law v. Siegel, 571 U.S. 415, 421 (2014) ("We have long held that "whatever equitable powers remain in the bankruptcy courts must and can only be exercised within the confines of" the Bankruptcy Code." (quoting Norwest Bank Worthington v. Alers, 485 U.S. 197, 206 (1988))).

113 G. Marcus Cole, The Federalist Cost of Bankruptcy Exemption Reform, 74 AM. BANKR. L.J. 227, 239-41 (2000). That being said, defining the relationship is often challenging. See In re English, 59 B.R. 460, 466-67 (Bankr. N.D. Ga. 1985) ("The overlay of complex substantive bankruptcy laws, as well as of detailed and complex Bankruptcy Rules and applicable federal and state non-bankruptcy law, results in a patchwork of multiple federal and state substantive and procedural law under a structure that poses many unresolved issues that are likely to take years to adjudicate and resolve.").

114 Butner v. United States, 440 U.S. 48, 54 (1979).

115440 U.S. 48 (1979).

116 Id. at 54; see also Stellwagen v. Clum, 245 U.S. 605, 613 (1918) (noting that many state laws are recognized and enforced in bankruptcy even though this results in a lack of uniformity).
} 
proceedings. ${ }^{117}$ Congress's refusal to displace state-created rights ${ }^{118}$ serves to "reduce uncertainty, to discourage forum shopping, and to prevent a party from receiving 'a windfall merely by reason of the happenstance of'" a federal insolvency proceeding. ${ }^{119}$ Although counter-intuitive, having different legal standards based on each state or territory's law is much more predictable and certain than 352 different standards, ${ }^{120}$ which is the number of bankruptcy judgeships. ${ }^{121}$ Indeed, absent precedent from the relevant court of appeals, ${ }^{122}$ each bankruptcy judge could adopt a different "equitable standard" divorced from the underlying substantive law. ${ }^{123}$

\section{A. Field Preemption in Bankruptcy Proceedings}

Although this Article provides a test for applying conflict preemption in federal insolvency cases, this test would be unnecessary if it could be inferred that Congress had intended to occupy the "field" in all debtor-creditor relations. As one might guess from the thesis of this Article, drawing such an inference would be erroneous. The three preeminent Supreme Court cases evaluating field preemption in the context of bankruptcy predate the Bankruptcy Code, and their teachings are far from clear. ${ }^{124}$ Conforming these cases, however, still yields some guiding principles. On the one hand, Congress preempted the fields of (a) granting a discharge and (b) distributing property in a bankruptcy case. On the other hand, state insolvency laws (y) providing for the sale and disposition of the 117 SEC v. Wells Fargo Bank, N.A., 848 F.3d 1339, 1344 (11th Cir. 2017).
118 Dennis F. Dunne, Stock Repurchase Agreements in Bankruptcy: A Tale of State Law Rights
Discarded, 12 BANKr. DeV. J. 355, 377-78 (1996).
$119 \quad$ Butner, 440 U.S. at 55 (quoting Lewis v. Mfrs. Nat'l Bank of Detroit, 364 U.S. 603, 605
$\begin{aligned} & (1961)) . \\ & 120 \quad \text { Status of Bankruptcy Judgeships - Judicial Business 2019, U.S. CTS., } \\ & \text { https://www.uscourts.gov/status-bankruptcy-judgeships-judicial-business-2019 (last visited Sept. }\end{aligned}$ 26, 2020).

121 Ralph Brubaker, Considering the Code's Preemptive Effect in the Plan Confirmation Context: State Utility Regulation and § 1123(a)(5) as a Case Study, 24 BANKr. L. LeTter, Feb. 2004.

122 Very few bankruptcy issues actually percolate to the level of circuit review. For a discussion of the various reasons and theories, consider Troy A. McKenzie, Judicial Independence, Autonomy, and the Bankruptcy Courts, 62 StAN. L. REv. 747, 783-84, 787-89 (2010).

123 Bankruptcy judges are not necessarily bound by the precedent of their district court superiors. See In re Ford, 415 B.R. 51, 60 (Bankr. N.D.N.Y. 2009), aff'd sub nom., Cmty. Bank, N.A. v. Ford, No. 5:09-CV-633 GLS, 2009 WL 9540679 (N.D.N.Y. Dec. 8, 2009) (observing that "[t]he issue of whether bankruptcy courts are bound by decisions of district court judges within the same district has not been definitively resolved" and holding that it was not bound by a district court decision).

124 See Effect of National Bankruptcy Act on State Insolvency Statutes, supra note 101 (describing field preemption under the 1898 Act as a "Delphic formula"). 
debtor's property to creditors without a discharge (such as an assignment of the benefit of creditors) or $(\mathrm{z})$ avoiding fraudulent transfers by a debtor are not subject to field preemption. ${ }^{125}$

In the earliest of the three cases, Stellwagen v. Clum, ${ }^{126}$ the Supreme Court announced the distinction between "bankruptcy laws" that are subject to field preemption and "insolvency laws" that are not. ${ }^{127}$ In Stellwagen, a state law providing for the avoidance of fraudulent conveyances was not preempted because it did not provide for the discharge of the debtor, one of the requisites for a "true bankruptcy law." ${ }^{28}$ Instead, the Court categorized it as only an insolvency law, which can coexist with a federal bankruptcy statute. ${ }^{129}$ This guidance is tempered by the admission, almost a century before Stellwagen, that the distinction between bankruptcy laws and insolvency laws is generally arbitrary and the overlap is significant. ${ }^{130}$ The opinion also did not foreclose the existence of other "requisites" for a bankruptcy law or "fields" subject to preemption. ${ }^{131}$

In International Shoe Co. v. Pinkus, ${ }^{132}$ the Supreme Court struck down an Arkansas receivership law that incentivized creditors to stipulate to the debtor's discharge in exchange for higher priority treatment of their claims. ${ }^{133}$ The Court concluded that Congress had occupied the "field" for discharges of debtors' liabilities and had not meant for debtors to be able to choose between the 1898 Bankruptcy Act and state law alternatives. ${ }^{134}$ Although the Court focused on the grant of discharge as the basis for preemption, it employed broad

\footnotetext{
125 Pobreslo v. Joseph M. Boyd Co., 287 U.S. 518, 521 (1933); Int'l Shoe Co. v. Pinkus, 278 U.S. 261, 265 (1929); Stellwagen v. Clum, 245 U.S. 605, 615-16 (1918).

128 Id. But see Deutsche Bank Tr. Co. Ams. v. Large Priv. Beneficial Owners (In re Tribune Co. Fraudulent Conveyance Litig.), 818 F.3d 98, 111 (2d Cir. 2016) (“Once a party enters bankruptcy, the Bankruptcy Code constitutes a wholesale preemption of state laws regarding creditors' rights."). Although Tribune's ultimate holding rested on conflict preemption principles, this quote is more reflective of a broad view of field preemption in bankruptcy proceedings. Indeed, other courts have already quoted it as supporting broad field preemption. See Lynch v. Lapidem Ltd. (In re Kirwan Offices S.A.R.L.), 592 B.R. 489, 511 (S.D.N.Y. 2018).

129 Id.

130 Sturges v. Crowninshield, 17 U.S. (4 Wheat.) 122, 194-96 (1819).

131 Stellwagen, 245 U.S. at 615.

132278 U.S. 261 (1929).

133 Id. at 265 . The debtor, although eligible to file a voluntary bankruptcy petition, was not eligible for a bankruptcy discharge because he had received such a discharge within the six years preceding when he filed his state court case. $I d$. at 264-65. The state procedure was held to be at odds with the federal act because the debtor "could not have obtained discharge under Bankruptcy Act ... and, in proceedings under that act, all his creditors would have been entitled to participate in distribution without releasing [him] as to unpaid balances." Id.

$134 \quad I d$
} 
language precluding states from enacting competing "bankruptcy laws." Unfortunately, the Court only identified one other type of law within the field of "bankruptcy laws," the equitable distribution of the property of the debtor in consideration for the discharge. ${ }^{135}$

The last of the trio, Pobreslo v. Joseph M. Boyd Co. ${ }^{136}$ considered whether the 1898 Bankruptcy Act preempted Wisconsin's statutory assignment for the benefit of creditors statute. ${ }^{137}$ In contrast to the state insolvency law considered in Pinkus, the statute in Pobreslo did not require or coerce creditors to release their claims in consideration for receiving a share of the liquidation proceeds distributed by the assignee. ${ }^{138}$ Because the state statute granted neither a discharge nor a release of claims, it was not suspended ${ }^{139}$ by passage of the 1898 Bankruptcy Act. ${ }^{140}$

The field preemption bases identified in Pinkus are consistent with general field preemption principles. ${ }^{141}$ The federal rights of a discharge and the distribution of property on account of a discharge are substantive rules directly regulating conduct, an appropriate foundation for field preemption. ${ }^{142}$ Expanding field preemption beyond these recognized examples is inconsistent with federal bankruptcy law's general status as a procedural overlay on state substantive law. ${ }^{143}$

\section{B. Conflict Preemption in Bankruptcy Proceedings}

The Supreme Court has evaluated field preemption's counterpart, conflict preemption, on only five occasions. In the first two, it clarified that state liquidation proceedings of insolvent debtors "are plainly preempted if they refuse

\footnotetext{
135 Id. at 265-66; see also Pobreslo v. Joseph M. Boyd Co., 287 U.S. 518, 525-26 (1933) (explaining Pinkus).

139 The enactment of federal bankruptcy legislation does not invalidate conflicting state laws but relegates them to a state of suspended animation until the next time Congress repeals federal bankruptcy legislation or allows it to lapse. Butler v. Goreley, 146 U.S. 303, 314 (1892); Tua v. Carriere, 117 U.S. 201, 209 (1886).

140 Pobreslo, 287 U.S. at 526.

141 See Ralph Brubaker, The Preemptive Effect of the Bankruptcy Code for Preference Avoidance Under State-Law Assignments for the Benefit of Creditors, 25 BANKR. L. LETTER, Apr. 2005.

$142 \quad I d$

$143 \quad I d$
} 
to yield to, or interfere with, federal bankruptcy proceedings." ${ }^{144}$ Later, it overturned two of its prior holdings in which a subjective test based on the state legislature's intent governed conflict preemption in bankruptcy proceedings. ${ }^{145}$

First, in In re Watts, ${ }^{146}$ the Court examined a contest between an Indiana state-court receiver and a subsequently-appointed receiver in bankruptcy for control over a debtor corporation's assets. ${ }^{147}$ In resolving questions related to the propriety of contempt sanctions imposed for noncompliance with conflicting orders of the state and federal courts, the Supreme Court explained that the state insolvency statute was not preempted by the very existence of the 1898 Bankruptcy Act (field preemption). ${ }^{148}$ Instead, the impossibility branch was triggered because both receivers were duty bound to administer the windup of the same corporation. ${ }^{149}$ The assets of the insolvent entity simply could not be administered by both a state court receiver and a bankruptcy receiver. ${ }^{150}$ Something had to give, and it was the authority of the state court and its receiver. ${ }^{151}$

Later, Straton v. New ${ }^{152}$ addressed a similar issue to Watts but came to a different result because concurrent jurisdiction existed. ${ }^{153}$ In Straton, a judgment lien creditor initiated an action in West Virginia state court to sell property subject to his lien and joined all parties holding liens and mortgages on the affected property. ${ }^{154}$ The state court appointed commissioners to sell the property and distribute the proceeds among the lienholders. ${ }^{155}$ A receiver pursuant to a

\footnotetext{
144 In re Newport Offshore Ltd., 219 B.R. 341 (Bankr. D.R.I. 1998) (first citing, inter alia, In re Watts, 190 U.S. 1, 23 (1903); and then citing Straton v. New, 283 U.S. 318 (1931)). Although the Newport court categorized Watts and Straton as field preemption cases, they are more appropriately categorized as conflict preemption cases.

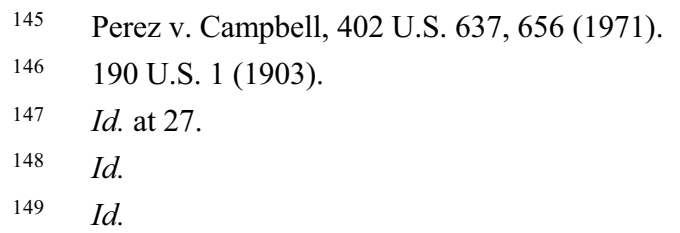

150 In re Milestone Educ. Inst., Inc., 167 B.R. 716, 723-24 (Bankr. D. Mass. 1994) (“[G]iven the control and supervision state courts and federal bankruptcy courts exercise over receiverships and bankruptcy cases, respectively, the two proceedings cannot coexist. ... Federal preemption compels the conclusion that the receivership must yield in all aspects to avoid this consequence so that the assets of the Debtor corporation can be garnered and distributed with finality in accordance with the Bankruptcy Code.").

151 Watts, 190 U.S. at 27 ("The bankruptcy law is paramount, and the jurisdiction of the Federal courts in bankruptcy, when properly invoked, in the administration of the affairs of insolvent persons and corporations, is essentially exclusive.").

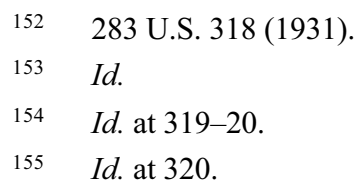


subsequently initiated bankruptcy case attempted to administer the same property. ${ }^{156}$ Because the 1898 Bankruptcy Act provided for concurrent jurisdiction in such a situation, no conflict existed. ${ }^{157}$ Indeed, in distinguishing the case from Watts, the Court explained that "[a]ssuming them to be receivers, their function is not that of an officer charged with winding up the affairs of the debtor, such as would cause a conflict with the bankruptcy law."158

Perez v. Campbell ${ }^{159}$ represents the Supreme Court's most recent evaluation of the obstacle branch of conflict preemption in the insolvency context. Perez arose from a challenge to an Arizona statute that precluded a bankruptcy discharge from releasing a driver's license suspension arising from an automobile accident judgment. ${ }^{160}$ Although the purpose of the Arizona statute was ostensibly to protect the public from dangerous drivers, it frustrated one of the principal purposes of the 1898 Bankruptcy Act: the fresh start debtors received pursuant to the discharge of prepetition debts. ${ }^{161}$ Thus, the Arizona statute constituted "an obstacle to the accomplishment and execution of the full purposes and objectives of Congress." 162 This conclusion ran counter to two earlier Supreme Court cases that had upheld state statutes substantially similar to the Arizona statute. ${ }^{163}$ These holdings validated the relevant state's subjective purpose, concern for highway safety, without considering the effects of the statute on federal interests. ${ }^{164}$ As the Court observed, this rule could easily be gamed by state legislatures who could publish legislative history "articulating some state interest or policy - other than frustration of the federal objectivethat would be tangentially furthered by the proposed state law." 165 More generally, this rule was unknown in any other conflict preemption context, and no reasons existed to create a subjective exception to obstacle preemption solely for bankruptcy matters. ${ }^{166}$ Accordingly, the two earlier precedents were overruled, and the Arizona statute was suspended. ${ }^{167}$

Watts and Perez are both consistent with general conflict preemption principles as they involved jurisdictional rules, state regulation of discharges or

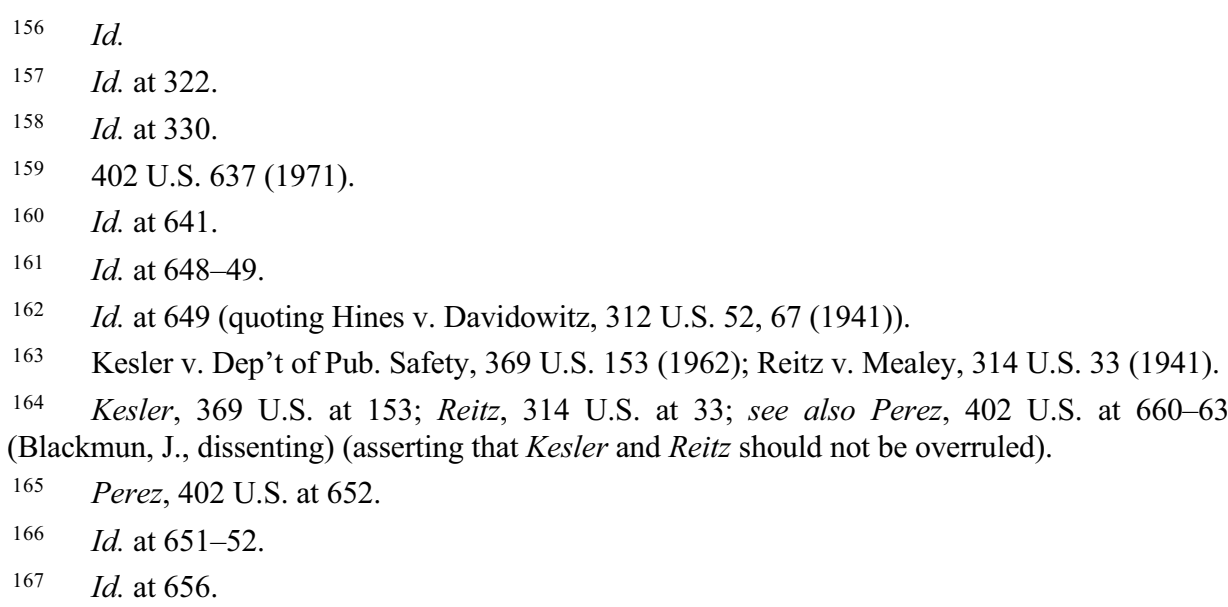


distribution of property in bankruptcy court custody. ${ }^{168}$ This is not the end of the story, however, as the pre-Code practice doctrine, 28 U.S.C. $§ 959$ (b), and the Supreme Court's teachings in Gillis and Midlantic all must be addressed to formulate a comprehensive test.

\section{Preemption and Federal Common Law Rules in Receivership Proceedings}

Lacking a comprehensive statutory scheme like the Bankruptcy Code, federal receivership law remains almost wholly the product of federal common law and local rules. Although Federal Rule of Civil Procedure 66 provides that the Federal Rules of Civil Procedure govern receivership actions in federal court, these rules say nothing about the process of administering the debtor's estate or distributing its assets. ${ }^{169}$ Instead, "the practice in administering an estate by a receiver or a similar court-appointed officer must accord with the historical practice in federal courts or with a local rule." ${ }^{170}$ Some courts have responded to

168 See In re Leslie, 520 F.2d 761, 762 (9th Cir. 1975); In re Brat, 527 B.R. 303, 313 (Bankr. M.D. Tenn. 2015) (concluding that a state's regulation of interest in an effort to allow a penalty that would otherwise not be allowable was preempted as conflicting with 11 U.S.C. $\S \S 502,506$, 511).

169 SEC v. Vescor Cap. Corp., 599 F.3d 1189, 1193 (10th Cir. 2010). One exception is 28 U.S.C. $\S \S 2001$ and 2004, which governs federal judicial sales of real and personal property, including those conducted by a receiver. Knauss v. Dwek, 289 F. Supp. 2d 546, 553 (D.N.J. 2003). This provision preempts conflicting state law that would otherwise govern such sales. Id. An interesting intra-federal conflict issue arises in those jurisdictions whereby local rule, Bankruptcy Code provisions, including 11 U.S.C. $§ 363$, govern sales of the debtor's property. Sections 2001 and 2004 of Title 28 also apply in those proceedings. It would appear that the local rule adopting the Bankruptcy Code would be invalidated as local rules must "be consistent with Acts of Congress." 28 U.S.C.A. $\$ 2071$ (West 2020). This default rule may not settle this issue as the "local rule" is a federal statute. Instead, resorting to intra federal statutory conflict preemption analysis may be required. Unfortunately, as one scholar has noted, "there has been little scholarly treatment as to how conflicts between federal statutes should be resolved. In the courts, various canons are invoked. Statutes should be read in harmony where possible. Old laws yield to new. General statutes yield to specific ones. Implied repeal is disfavored." Maher, supra note 30 (internal citations omitted).

170 FED. R. Civ. P. 66. As explained in the Advisory Committee's Note, "[ $t]$ he last sentence added to Rule 66 assures the application of the rules to all matters except actual administration of the receivership estate itself." Id. advisory committee's note to 1946 amendment. In the only significant published opinion evaluating the scope of Rule 66, the Second Circuit established commonsense definitions of both administration and practice. Phelan v. Middle States Oil Corp., 210 F.2d 360, 363 (2d Cir. 1954).:

"Administration" means the receiver's dealings with the property, and the "practice" in such administration refers to orders he must get to allow him to dispose of the property, to spend money to protect it, to distribute it among the creditors or lienors, and the like. In short, the "practice" means the procedure by which he gets the power to do those things which an owner of the property would have without court authorization.

Id. 
the absence of a federal receivership statute by adopting local rules replicating the administration of federal bankruptcy law as the governing law for receivership cases. ${ }^{171}$ In those jurisdictions, bankruptcy preemption rules apply. ${ }^{172}$

Where local rules provide no guidance, historical federal principles govern "administration" and "practice." 173 Historical principles mean those existing as of the amendment to Rule 66, which was promulgated by the Supreme Court in $1946 .{ }^{174}$ In the absence of an applicable local rule, they form "a normative standard for uniform administration of receiverships." $"$ In In these jurisdictions, which lack a comprehensive statutory framework, preemption is illusory. ${ }^{176}$ No evidence of congressional intent exists to support preemption. ${ }^{177}$

Instead, federal common law rules ${ }^{178}$ play an analogous role to conflict preemption. In a proceeding where a federal common law rule governs, the rule

171 Indeed, in some jurisdictions, the Bankruptcy Code itself governs receivership pursuant to local rule. E.g., SEC v. Labry, No. SACV 10-00018-JVS (ANx), 2010 WL 11595854 at *1 (C.D. Cal. June 7, 2010) ("Local Rule 66-8 provides that receivership estates should be administered as though they were estates in bankruptcy."); N.D. Ohio Civ. L.R. 66.1(d) (“[T] he receiver or similar officer shall administer the estate as nearly as may be in accordance with the practice in the administration of estates in bankruptcy, except as otherwise ordered by the Court."); S.D. Ind. L.R. 66-1(d) ("In all other respects the [receiver] must - to the extent it is reasonable to do soadminister the estate in the way that bankruptcy estates are typically administered unless the court authorizes a different practice.”); W.D. Mo. L.R. 66.1(e) (“Unless the Court orders otherwise, in all other respects, the receiver or similar officer must administer the estate as nearly as may be in accordance with the practice in the administration of estates in bankruptcy."); see also D.N.J.L. Civ. R. 66.1(h) (providing that compensation of receivers, attorneys and other professionals in a receivership case "shall be guided by the standards fixed for compensation of such officers in connection with proceedings under the Bankruptcy Code").

172 See sources cited supra note 171.

173 Phelan, 210 F.2d at 363.

174 FED. R. Civ. P. 66 advisory committee's note to 1946 amendment; Janvey v. Alguire, No. 3:09-CV-0724-N, 2014 WL 12654910, at *14 (N.D. Tex. July 30, 2014), aff'd, 847 F.3d 231 (5th Cir. 2017) ("Thus, it is clear that Congress intended for federal equity receiverships to function as they had at common law, unless otherwise noted.").

175 Can. Life Assur. Co. v. LePeter, 563 F.3d 837, 842 (9th Cir. 2009); see also 12 Charles Alan Wright, Arthur R. Miller \& Richard L. Marcus, Federal Practice and Procedure $\S 2983$, at 33-35 (2d ed. 1997).

176 Michelle M. Harner, Rethinking Preemption and Constitutional Parameters in Bankruptcy, 59 WM. \& MARY L. REV. 147, 206 (2017).

177 Id.

178 Any time federal common law is mentioned, a discussion of the Erie Doctrine necessarily follows. Erie greatly limits the federal courts' authority to apply federal common law rules to preempt state law claims. Erie R.R. Co. v. Tomkins, 304 U.S. 64, 83 (1938). Put another way, it places the onus on Congress to enact statutes that displace state law matters of substance. Id. at 87. Given that Rule 66 provides for federal common law to govern the administration and practice of a receiver absent a local rule, Liberte Cap. Group, L.L.C. v. Capwill, 462 F.3d 543, 551 (6th Cir. 
may either incorporate state law or apply a uniform federal common law rule. ${ }^{179}$ When state law is incorporated, the result is akin to a finding of no preemption. ${ }^{180}$ When the state law is not incorporated, no "preemption" occurs, but the application of a uniform federal rule causes the same result, federal law, not state law, applies. This is why uniform federal common law can accurately be termed "judicial preemption." 181

Akin to the limited role of preemption in bankruptcy proceedings, few federal common law rules fail to incorporate state law in receivership proceedings. "When a district court creates a receivership, its focus is 'to safeguard the assets, administer the property as suitable, and to assist the district court in achieving a final, equitable distribution of the assets if necessary.""182 Although federal receivership law could always apply uniform federal common

2006), and the timing of the promulgation of Rule 66 after Erie means that federal common law was intended to displace state law, if done so historically. Nonetheless, Erie still applies when state law claims are brought in receivership proceedings as third-party complaints, unless there is a sufficient need for uniformity or another federal interest. Compare O'Melveny \& Myers v. FDIC, 512 U.S. 79, 87 (1994) (refusing to apply federal common law imputation rules to third party complaint in receivership), with Terry v. June, 359 F. Supp. 2d 510, 518 (W.D. Va. 2005), order amended on reconsideration, 420 F. Supp. 2d 493 (W.D. Va. 2006) (applying uniform federal common law rule for fraudulent transfers and distinguishing O'Melveny on the basis that the receiver was appointed under the Financial Institutions Reform, Recovery, and Enforcement Act not as an equity receiver). In contrast to receivership law, the application of federal common law rules is much more limited in bankruptcy as "the power to override state law . . . is not to be found in federal equity jurisdiction as such but can be derived only from constitutional and statutory bankruptcy sources." Alfred Hill, The Erie Doctrine in Bankruptcy, 66 HARV. L. REV. 1013, 1019 (1953). The Butner principle, supra note 116 and accompanying text, reflects the application of the Erie doctrine in bankruptcy. See Cameron J. Schlagel, Bankruptcy, Debt Recharacterization, and the Constitution: An Erie Relationship, 93 Am. BANKR. L.J. 1, 32-33 (2019). Nonetheless, some scholars have asserted that a general federal common law rule of bankruptcy is the foundation for all non-statutory powers of bankruptcy courts, rather than bankruptcy courts' general equity powers. See Adam J. Levitin, Toward a Federal Common Law of Bankruptcy: Judicial Lawmaking in a Statutory Regime, 80 AM. BANKR. L.J. 1, 66-78 (2006); see also Ralph Brubaker, Subordinated Debt and Postpetition Interest: The Rule of Explicitness Refuses To Die, 32 BANKR. L. LETTER, Feb. 2012 (asserting that the Rule of Explicitness is a federal bankruptcy-specific common law construct). Regardless of the scholarly merits of this latter position, most courts appear to view bankruptcy courts as courts of equity in spite of Erie, rather than creators of federal common law. Padilla v. GMAC Mortg. Co. (In re Padilla), 389 B.R. 409, 429 (Bankr. E.D. Pa. 2008) (listing cases). The Supreme Court has preferred to label these extra-statutory powers as inherent powers. Law v. Siegel, 571 U.S. 415, 421 (2014). Regardless of the nomenclature, the Supreme Court has circumscribed that equity/common law/inherent powers "do[] allow the bankruptcy court to override explicit mandates of other sections of the Bankruptcy Code." Id.

179 City of Milwaukee v. Illinois, 451 U.S. 304, 313 (1981).

180 Kunin v. Benefit Tr. Life Ins. Co., 898 F.2d 1421, 1427 (9th Cir. 1990), opinion amended and superseded, 910 F.2d 534 (9th Cir. 1990).

181 Paul Lund, The Decline of Federal Common Law, 76 B.U. L. REv. 895, 967 (1996).

182 SEC v. Vescor Cap. Corp., 599 F.3d 1189, 1194 (10th Cir. 2010) (quoting Liberte Cap.

Grp., L.L.C. v. Capwill, 462 F.3d 543, 551 (6th Cir. 2006)). 
law rules to administer proceedings in conformance with these interests, ${ }^{183}$ federal receivership law's traditional status as a procedural framework forestalls this result. ${ }^{184}$ This default view is consistent with the principle that federal common law "should usually incorporate the applicable state law." 185 Unless a compelling federal interest exists, state law should still apply. ${ }^{186}$

The treatment of in rem interests in receivership proceedings reflect these principles. As the Supreme Court confirmed, "a receiver appointed by a federal court takes property subject to all liens, priorities, or privileges existing or accruing under the laws of the State." 187 Thus, the in rem rights of creditors existing under state law are unaltered, even if they constitute an obstacle to the federal interest in equitable distributions to creditors; the federal common law incorporates state law. ${ }^{188}$

In contrast, when the underlying state law frustrates the historical receivership principles of the receivership, the receivership court will apply a uniform federal common law rule. ${ }^{189}$ In the case of distributing the debtor's

183 Nat'l P'ship Inv. Corp. v. Nat'l Hous. Dev. Corp., 153 F.3d 1289, 1291 (11th Cir. 1998) (" $[\mathrm{T}] \mathrm{o}$ the extent Rule 66 dictates what principles should be applied to federal receiverships, courts must comply with the Rule even in the face of differing state law.").

184 See SEC v. Wells Fargo Bank, 848 F.3d 1339, 1344 (11th Cir. 2017); In re Real Prop. Located at Redacted Jupiter Drive, Salt Lake City, Utah, No. 2:05-CV-1013, 2007 WL 7652297, at *4 (D. Utah Sept. 4, 2007)

185 Fed. Home Loan Mortg. Corp. v. Riverdale Bank, No. 92 C 1332, 1992 WL 73539, at *1 (N.D. Ill. Mar. 27, 1992) (citing United States v. Kimbell Foods, Inc., 440 U.S. 714 (1979)).

186 Id. at $* 2$.

187 Marshall v. New York, 254 U.S. 380, 385 (1920) (granting the state of New York a priority right to receivership assets over unsecured creditors, based on state law); see also Ticonic Nat'l Bank v. Sprague, 303 U.S. 406, 412 (1938) (quoting Scott v. Armstrong, 146 U.S. 499, 510 (1892) ("LL]iens, equities, or rights arising ... prior to insolvency and not in contemplation therof, are not invalidated.”)); SEC v. Mgmt. Sols., Inc., No. 2:11-CV-01165-BSJ, 2013 WL 594738, at *3 (D. Utah Feb. 15, 2013).

188 Sprague, 303 U.S. at 411-12 ("[T] there is manifestly an inequality of rights between the secured and unsecured creditors, which cannot be affected by the principal of equality of distribution."); see also Mfrs.' Fin. Co. v. McKey, 294 U.S. 442, 449 (1935) (The receiver was bound by valid contract under state law regardless of how "strong an appeal may be to the conscience of a chancellor for equitable relief."). One in rem right that receivership courts have curtailed in the name of equity is tracing. Going back to the case of Charles Ponzi in Cunningham v. Brown, 265 U.S. 1 (1924), the Supreme Court declined to apply tracing principles because it would be inequitable to other victims who had substantially similar claims as victims of the scheme. Id. at 13. Instead, "equality is equity." Id.; see also SEC v. Elliott, 953 F.2d 1560, 1570 (11th Cir. 1992); Commodity Futures Trading Comm'n v. Franklin, 652 F. Supp. 163 (W.D. Va. 1986), rev'd on other grounds, Anderson v. Stephens, 875 F.2d 76 (4th Cir. 1989).

189 Federal common law is implemented when "Congress has given the courts the power to develop substantive law.” Texas Indus., Inc. v. Radcliff Materials, Inc., 451 U.S. 630, 641 (1981). Rule 66 of the Federal Rules of Civil Procedure grants Federal receivership courts exactly this authority. FED. R. CIV. P. 66. 
assets, even though field preemption (the basis for preemption in this context in bankruptcy proceedings) is not available due to the lack of a statutory framework, the federal interest, "the fair distribution of the liquidated assets," is identical. ${ }^{190}$ Because the receivership court has the historical power to "ensure that the proposed plan of distribution is fair and reasonable," $" 191$ it also has the authority under federal common law to craft an equitable distribution independent of and distinct from state law. ${ }^{192}$ One historical example is the disallowance of interest accruing on the claims of under-secured creditors after a receivership is ordered. ${ }^{193}$ The under-secured creditor's claim will be disallowed even though the creditor would have been entitled to interest under state law. ${ }^{194}$ More modernly, receivership courts have relied upon this principle to deny distributions to under-secured creditors for deficiency claims above the value of collateral and to treat creditors differently based on the control they gave the

190 SEC v. Wealth Mgmt. L.L.C., 628 F.3d 323, 334 (7th Cir. 2010) (citing In re Envirodyne Indus., 79 F.3d 579, 582 (7th Cir. 1996)); see also SEC v. Stanford Int'l Bank, No. 17-10663, 2019 WL 2496901, at *5 (5th Cir. June 17, 2019) (“"TT]he purpose of bankruptcy receiverships and equity receiverships is essentially the same - to marshal assets, preserve value, equally distribute to creditors, and, either reorganize, if possible, or orderly liquidate." (internal quotations omitted)).

191 Wealth Mgmt. L.L.C., 628 F.3d at 332 (citing Off. Comm. of Unsecured Creditors of WorldCom v. SEC', 467 F.3d 73, 84 (2d Cir. 2006)); see also Janvey v. Alguire, No. 3:09-CV0724-N, 2014 WL 12654910, at*17 (N.D. Tex. July 30, 2014), aff'd, 847 F.3d 231 (5th Cir. 2017) ("This makes sense, seeing as federal equity receiverships were the predecessor to Chapter 7 liquidations and Chapter 11 reorganizations.").

192 Mgmt. Sols., Inc., 2013 WL 594738, at *2-3 (citing United States v. Vanguard Inv. Co., 6 F.3d 222, 226 (4th Cir. 1993); and then citing SEC v. Elliott, 953 F.2d 1560, 1569 (11th Cir. 1992)); see also Liberte Cap. Grp., L.L.C v. Capwill, 421 F.3d 377, 384 (6th Cir. 2005) (“[E]quity and justice are appropriate considerations for distribution.").

193 Mgmt. Sols., Inc., 2013 WL 594738, at*3.

194 Ticonic Nat'l Bank v. Sprague, 303 U.S. 406, 411 (1938) ("It is in order to assure equality among creditors as of the date of insolvency that interest accruing thereafter is not considered."); United States v. Sullivan, 254 F. Supp. 254, 256 (D.R.I. 1966) (listing supportive cases). The policy supporting this common law rule is the "federally-caused delay" occasioned by the institution of the receivership proceedings. Hill, supra note 178, at 1017; see also Thomas v. W. Car Co., 149 U.S. 95, 116-17 (1893). This policy was also applied in bankruptcy cases. Vanston Bondholders Protective Comm. v. Green, 329 U.S. 156, 164 (1946); Sexton v. Dreyfus, 219 U.S. 339, 344 (1911). Justice Frankfurter criticized the federal common law rule in his concurrence in Vanston Bondholders Protective Comm. v. Green, where he suggested interest allowable under state law is allowable in bankruptcy because state law establishes whether a claim exists, including any accrual of interest. 329 U.S. 156, 170-71 (1946) (Frankfurter, J., concurring). It is no longer a creature of common law as "Congress codified the longstanding practice of disallowing postpetition interest on unsecured claims in both the 1898 Act (in $\S 63 \mathrm{a}(1) \&(5)$ ) and the current Bankruptcy Code (in $\S 502(\mathrm{~b})(2))$." Brubaker, supra note 178 . Private parties, through a contractual subordination agreement, can contract around this rule and allow a senior secured party to receive payment of post-petition interest in full prior to any distribution to junior creditors. This construct is known as the Rule of Explicitness. Id. 
wrongdoing principal over their investments. ${ }^{195}$ Looking beyond distributions to creditors, state law does not authorize receivers to reject leases or sell property free and clear of liens. Nonetheless, federal common law standards have been incorporated as the rule of decision and applied to authorize these actions. ${ }^{196}$ To reject leases or sell property free and clear, federal common law standards have been incorporated as the rule of decision. ${ }^{197}$

\section{28 U.S.C. $§ 959$, ITS HISTORY, AND PREEMPTION}

Congress first enacted the predecessor to 28 U.S.C. $§ 959$ (b) in $1887 .{ }^{198}$ The original text was

That whenever in any cause pending in any court of the United States there shall be a receiver or manager in possession of any property such receiver or manager shall manage and operate such property according to the requirements of the valid laws of the State in which such property shall be situated in the same manner the owner or possessor thereof would be bound to do if in possession thereof. ${ }^{199}$

195 SEC v. Enter. Tr. Co., 559 F.3d 649, 652 (7th Cir. 2009) (affirming plan of distribution that provided for greater payouts to custodial investors rather than those managed by fraudulent principal on the basis that they had less knowledge of the fraud); SEC v. Byers, 637 F. Supp. 2d 166, 183 (S.D.N.Y. 2009), aff'd sub nom., SEC v. Malek, 397 F. App'x 711 (2d Cir. 2010), aff'd sub nom., SEC v. Orgel, 407 F. App'x 504 (2d Cir. 2010) (denying distribution to deficiency claims).

196 Janvey, 2014 WL 12654910, at *10; Plymouth Mills, Inc. v. FDIC, 876 F. Supp. 439, 442 (E.D.N.Y. 1995) (explaining that the authority of receivers to reject leases was recognized at least as early as the Supreme Court's holding in Sunflower Oil Co. v. Wilson, 142 U.S. 313, 322 (1892), and acknowledging that a receiver has a "reasonable time" to make the determination whether rejection is proper); Ellsworth E. Clark, Henry E. Foley \& Oscar M. Shaw, Adoption and Rejection of Contracts and Leases by Receivers, 46 HARV. L. REV. 1111, 1111 (1933) ("Courts and textwriters commonly state that a receiver may elect to adopt or to reject contracts and leases, and that he has a reasonable time within which to make such election.").

197 Compare Pennant Mgmt., Inc. v. First Farmers Fin., L.L.C., No. 14-CV-7581, 2015 WL 4511337, at *4 (N.D. Ill. July 24, 2015) (citing Regions Bank v. Egyptian Concrete Co., No. 09cv-1260, 2009 WL 4431133, at*7 (E.D. Mo. Dec. 1, 2009)), and 2 Clark ON ReCEIVERS § 500(b) (3d ed. 1959), with Dir. of Transp. v. Eastlake Land Dev. Co., 894 N.E.2d 1255, 1261 (Ohio Ct. App. 2008) (requiring consent of lien holders to sell free and clear), and In re Newport Offshore Ltd., 219 B.R. 341, 348 n.15 (Bankr. D.R.I. 1998) (noting that Rhode Island statute governing receiverships required consent of lien holders to sell property free and clear).

198 Briarcliff v. Briarcliff Tenants Ass'n, 15 B.R. 864, 866 (D.N.J. 1981).

$199 \quad I d$. 
In sum, a receiver or manager was required to follow the state law when operating or managing property in its possession. ${ }^{200}$ This has always been and continues to be the meaning of 28 U.S.C. $\S 959$ (b) and its predecessors. In 1911, Congress slightly amended the language of the statute but did not alter its substantive terms when it enacted 28 U.S.C. $§ 124 .^{201}$ In 1948, Congress codified 28 U.S.C. $\S 959$ (b) as the successor to 28 U.S.C. $\S 124 .{ }^{202}$ Besides carving out an exception for railroad reorganizations, the enactment of the Bankruptcy Code in 1978 did not alter the substance of 28 U.S.C. $\S 959(b) .{ }^{203}$ No legislative history explaining the scope of 28 U.S.C. $§ 959$ (b), its predecessors, or any associated amendments exists. This lack of guidance leaves the scope of 28 U.S.C. $\S 959$ (b) unclear. As a result, the search for meaning must start with the words of the statute and the Supreme Court's evaluations.

In spite of its age, the wording of 28 U.S.C. $\S 959(\mathrm{~b})$, including the phrase "manage and operate the property," has remained undefined by the Supreme Court. ${ }^{204}$ Without specific guidance, the next step is to evaluate the plain language of the words "manage" and "operate." 205 Courts often consult dictionary definitions to determine the meaning of ordinary words. ${ }^{206}$ The dictionary definition of "manage" is "to handle or direct with a degree of skill," while "operate" is defined as "to cause to function." "207 Section 959(b) uses the conjunction "and" to impose the requirement that an Estate Representative must

\footnotetext{
200 Peirce v. Van Dusen, 78 F. 693, 701 (6th Cir. 1897).

$201 \quad$ See 28 U.S.C.A. $\S 959$ (West 2020).

202 Briarcliff, 15 B.R. at 867.

203 Id. The exception for railroad reorganization still requires a trustee or debtor in possession to abide by applicable state or federal law, with the exception of the abandonment procedure under 11 U.S.C. § 1170. In re Chi., Mo. \& W. Ry., 156 B.R. 567, 572-73, 572 n.4 (Bankr. N.D. Ill. 1993). This remains the current language of 28 U.S.C. $§ 959(b)$ :

Except as provided in section 1166 of title 11, a trustee, receiver or manager appointed in any cause pending in any court of the United States, including a debtor in possession, shall manage and operate the property in his possession as such trustee, receiver or manager according to the requirements of the valid laws of the State in which such property is situated, in the same manner that the owner or possessor thereof would be bound to do if in possession thereof.
}

28 U.S.C.A. $§ 959$ (b).

204 In re Quanta Res. Corp., 739 F.2d 912, 919 (3d Cir. 1984), aff'd sub nom., Midlantic Nat'l Bank v. N.J. Dep't of Env't Prot., 474 U.S. 494 (1986).

205 Courts first analyze the plain language of a statute in an effort to parse its meaning. United States v. Ron Pair Enters., 489 U.S. 235, 241 (1989).

206 See FDIC v. Meyer, 510 U.S. 471, 476 (1994).

207 See Manage, MERRIAM-WEBSTER.COM, https://www.merriamwebster.com/dictionary/manage (last visited Sept. 25, 2020); Operate, MERRIAM-WEBSTER.COM, https://www.merriam-webster.com/dictionary/operate (last visited Sept. 25, 2020). Both "manage" and "operate" are used as transitive verbs in 28 U.S.C. $§ 959$ (b), and the definitions quoted in this paragraph reflect this categorization. 
both manage and operate the property in the Estate Representative's possession. Combining the plain language and dictionary definitions, 28 U.S.C. $§ 959$ (b) requires an Estate Representative to follow the requirements of applicable state law when both (i) handling and directing the property in the trustee's possession with a degree of skill and (ii) causing the same property to function.

Although the last section of this Article is devoted to the circuit split over whether 28 U.S.C. § 959(b) applies equally to liquidating and operating Estate Representatives, an otherwise comprehensive explanation of the scope of 28 U.S.C. $\S 959$ (b) is appropriate at this juncture. The plain language of the statute removes certain proceedings from the scope of 28 U.S.C. $\S 959$ (b). Perhaps the most obvious is a debtor's discharge, which does not implicate the property in the Estate Representative's possession. ${ }^{208}$ The distribution of a debtor's property to its creditors based on the applicable priority scheme requires actions by the Estate Representative, but those actions are wholly a product of federal law. There is no state law for the Estate Representative to follow. Consistent with the interpretation of the plain language of 28 U.S.C. § 959(b), the Supreme Court has already implicitly confirmed that both discharge and the distribution of a debtor's property on account of the discharge are governed by field preemption ${ }^{209}$ or general conflict preemption principles, ${ }^{210}$ without evaluating 28 U.S.C. $\S 959$ (b). Another common component of insolvency proceedings outside the scope of 28 U.S.C. $\S 959(\mathrm{~b})$ is the claims allowance process. It evaluates the viability of a creditor's claim against the debtor's estate. ${ }^{211}$ Because a creditor's claim arises prior to the insolvency proceeding, the Estate Representative's actions are irrelevant.

For a statute with such a lengthy history, the Supreme Court has only analyzed 28 U.S.C. $§ 959$ (b) and its predecessors a few times, mostly in the first half of the 20th Century. All of these opinions share one theme: a focus on preemption. ${ }^{212}$ The culmination of these early cases was the 1934 opinion of

\footnotetext{
208 Although there is some dispute whether discharge is an in rem proceeding. Robert W. Miller, Everything Old Is New Again: Why the In Rem Summary Jurisdiction of the 1898 Bankruptcy Act Still Limits the Constitutional Authority of Bankruptcy Judges, 89 AM. BANKR. L.J. 1,9 (2015) (arguing it is a proceeding regarding the res, if any, of the debtor, not the Estate Representative).

209 See Int'1 Shoe Co. v. Pinkus, 278 U.S. 261, 265 (1929).

210 See Perez v. Campbell, 402 U.S. 637, 649 (1971); In re Watts, 190 U.S. 1, 27 (1903); SEC v. Wealth Mgmt. L.L.C., 628 F.3d 323, 334 (7th Cir. 2010) (stating 28 U.S.C. § 959(b) has no relevance on its face to distribution determinations); In re Drexel Burnham Lambert Grp. Inc., 151 B.R. 684, 693 (Bankr. S.D.N.Y. 1993) (applying the usual conflict preemption framework to distribution of debtor's property).

211 Wealth Mgmt. L.L.C., 628 F.3d at 334 (stating 28 U.S.C. § 959(b) has no relevance on its face to claims allowance process).

212 In United States v. Harris, the Supreme Court determined that Congress had not meant for the underlying federal law to apply to receivers, and as a result, 28 U.S.C. $§ 124$ was not applicable.
} 
Gillis v. State of California where the Supreme Court implicitly confirmed the status of 28 U.S.C. $§ 959$ (b) as a specific saving clause. ${ }^{213}$ Only after considering this fact, does the treatment of 28 U.S.C. $\S 959(\mathrm{~b})$ in the Midlantic majority opinion make sense. The Supreme Court's recent citation to 28 U.S.C. $§ 959$ (b) in Mission Products Holdings, Inc. v. Tempnology, L.L.C. ${ }^{214}$ only strengthen the case for characterizing it as a specific saving clause.

A. Gillis

Gillis articulated the applicable preemption analysis when 28 U.S.C. $\S 959$ (b) is triggered. In Gillis, a receiver appointed by a federal district court to operate a business was required to obtain a surety bond to assure the payment of taxes. ${ }^{215}$ The surety subsequently refused to renew the bond, and the receiver could not obtain a replacement. ${ }^{216}$ The receiver asserted that the state law requiring the bond would frustrate the purpose of the receivership and, absent authorization to continue to operate without the bond, the company would be liquidated. ${ }^{217}$ The district court allowed the receiver to continue operations in spite of his failure to obtain a replacement bond. After the Ninth Circuit reversed the district court, ${ }^{218}$ the Supreme Court affirmed the Ninth Circuit. Before the Supreme Court, the receiver asserted that the applicable state laws should be preempted because they diminished the authority of the federal court by constraining its receiver. ${ }^{219}$ The Supreme Court rejected the receiver's argument and explained the receiver's mischaracterization of the preemption issue. ${ }^{220}$ Pursuant to 28 U.S.C. $\S 124$, the question was not whether the state law infringed on the rights of the receiver, rather, it was whether the state law "conflict[s] with the [C]onstitution or laws of the United States." 221 Thus, if a state statute conflicted with federal insolvency law, the federal law would prevail. ${ }^{222}$ The Court found that no conflict existed between the state law and federal

177 U.S. 305, 308-09 (1900). In the same year, in Erb v. Morasch, the Supreme Court evaluated whether a state statute conflicted with the United States Constitution and, finding that the state statute did not create conflict, held that the receiver would be entitled to follow it in the jurisdiction where it governed. 177 U.S. 584, 585-86 (1900).

213 Gillis v. California, 293 U.S. 62, 63 (1934).

214139 S. Ct. 1652 (2019).

215 Gillis, 293 U.S. at 64

$216 \quad I d$.

$217 \quad$ Id.

218 California v. Gillis, 69 F.2d 746 (9th Cir. 1934), aff'd, 293 U.S. 62 (1934).

219 Gillis, 293 U.S. at 64.

$220 \quad I d$. at 65.

221 Id.; see also Erb v. Morasch, 177 U.S. 584, 586 (1900).

222 See In re Stable Mews Assocs., Inc., 41 B.R. 594, 599 (Bankr. S.D.N.Y. 1984) (analyzing Gillis, 293 U.S. at 65). 
receivership law. No preemption analysis was required, and the receiver was required to follow state law and either obtain a bond or cease operations. The Court concluded that, "if the receiver cannot continue to carry on the Company's business according to the plain direction of Congress [in 28 U.S.C. $\S 124$ ], he must pursue some other course permitted by law."223

Gillis endorsed 28 U.S.C. § 959(b)'s alteration of the default preemption analysis by requiring an Estate Representative to follow state law when he is operating or managing the debtor's property in the ordinary course, ${ }^{224}$ irrespective of the obstacle posed by the state law. ${ }^{225}$ Unless it presents a direct conflict, an Estate Representative must follow a state law even if it presents an obstacle to accomplishing the goals of bankruptcy or receivership law. ${ }^{226}$ To wit, the Supreme Court expressly failed to evaluate whether the bond requirement under state law created a sufficient obstacle to support preemption. Instead, given there was no direct conflict and the state law was constitutional, ${ }^{227}$ the receiver was forced to comply irrespective of the obstacle it imposed.

Gillis's analysis substantiates 28 U.S.C. $§ 959(b)$ 's status as a specific saving clause and its elimination of the obstacle prong of conflict preemption. ${ }^{228}$

\footnotetext{
223 Gillis, 293 U.S. at 66; Burke v. Morphy, 109 F.2d 572, 575 (2d Cir. 1940).
}

224 Court authorization is generally not required for an Estate Representative to operate in the ordinary course. See 11 U.S.C.A $\S 363(c)(1)$ ("[U]nless the court orders otherwise, the trustee may enter into transactions, including the sale or lease of property of the estate, in the ordinary course of business, without notice or a hearing, and may use property of the estate in the ordinary course of business without notice or a hearing").

225 See In re Vel Rey Props., Inc., 174 B.R. 859, 864 (Bankr. D.D.C. 1994) (explaining that Gillis's holding means that an Estate Representative cannot exercise its business judgment to violate state law); cf. Carlos J. Cuevas \& Bruce L. Weiner, Judicial Code $\S$ 959(b) and Its Relationship to the Automatic Stay-Part I, AM. BANKR. InST. J., Sept. 1997, at 8, 8 ("[T] he court was adverse to inferring preemption of valid state laws, especially when Congress had enacted Judicial Code $\S 65$, which authorized the enforcement of state and local health and safety laws.").

226 See In re Cajun Elec. Power Coop., Inc., 185 F.3d 446, 453-54 (5th Cir. 1999) ("[W]e agree with our sister circuits that 'the import' of this section is that the 'general bankruptcy policy of fostering the rehabilitation of debtors will not serve to preempt otherwise applicable state laws dealing with public safety and welfare." (quoting Robinson v. Mich. Consol. Gas Co., 918 F.2d 579, 589 (6th Cir. 1990))).

227 See Ky. Emps. Ret. Sys. v. Seven Cntys. Servs., Inc., 823 F. App’x 300, 304 (6th Cir. 2020) ("[Section] 959(b)'s plain language does not allow a debtor to selectively choose which valid state laws to follow."); Burke v. Morphy, 109 F.2d 572, 575 (2d Cir. 1940) (“A receiver appointed by a federal court must manage and operate the property according to the requirements of the valid laws of the state."); see also In re Penn Cent. Transp. Co., 347 F. Supp. 1356, 1366 (E.D. Pa. 1972).

228 The efficacy of the test is not predicated on the status of 28 U.S.C. $\S 959$ (b) as a specific saving clause and the effect of such categorization. Gillis confirms that 28 U.S.C. § 959(b) renders the obstacle prong inapplicable regardless of its taxonomy. Moreover, any critique that Gillis predated the commencement of the obstacle preemption case line, see Hines v. Davidowitz, 312 U.S. 52, 67 (1941), is defused by the Supreme Court's subsequent evaluation of 28 U.S.C. $\S 960$ in California State Board of Equalization v. Sierra Summit, Inc., 490 U.S. 844, 852-53 (1989). As 
Although 28 U.S.C. $\S 959$ (b) is an anti-preemption clause, the usual boilerplate terms, including "inconsistent with" the federal statute, are conspicuously absent. ${ }^{229}$ Section 959(b) specifies when state law must be followed by identifying (i) the person or entity (the Estate Representative), (ii) what actions the Estate Representative must be taking (management or operation), and (iii) the quantum of control required to trigger the requirement (possession). ${ }^{230}$ This degree of specificity, together with the omission of any reference to inconsistency with federal law, illustrates congressional intent to avoid preempting state laws that may constitute obstacles to the purposes of federal insolvency law. ${ }^{231}$ Gillis's treatment of 28 U.S.C. $\S 959(\mathrm{~b})$ verifies this conclusion. The status of 28 U.S.C. $§ 959$ (b) as a specific saving clause means state law is not generally an obstacle to the management and operation by an Estate Representative. Or, in the words of Gillis, "if the receiver cannot continue to carry on the Company's business according to the plain direction of Congress [by following state law], he must pursue some other course permitted by law."232 Although specific saving clauses eliminate the traditional obstacle preemption analysis, their application "cannot be held to destroy [the federal statute]." 233 Thus, a direct and unambiguous conflict between federal insolvency law and state law would be sufficient to trigger preemption. Gillis evaluated whether a direct conflict between the state law requirement for a bond and federal law existed. Finding none, it refused to apply an obstacle preemption analysis. This

\footnotetext{
discussed more fully in Part VI, the Supreme Court relied on contemporaneous case law in holding that 28 U.S.C. $§ 960$, a statute generally requiring Estate Representatives to pay applicable taxes, "indicates a Congressional purpose to facilitate - not to obstruct - enforcement of state laws." Id. (quoting Boteler v. Ingels, 308 U.S. 57, 60-61 (1939)). Moreover, "[i]f Congress wished to declare otherwise, its intent would have to 'be clearly expressed, not left to be collected or inferred from disputable considerations of convenience in administering the estate of the bankrupt."' $I d$. at 854 (quoting Swarts v. Hammer, 194 U.S. 441, 444 (1904)). As a result, Gillis is to 28 U.S.C. § 959(b) as Boteler and Swarts are to 28 U.S.C. $\S 960$.

229 See supra note 74.

$230 \quad$ See 28 U.S.C.A. § 959(b) (West 2020)

23128 U.S.C. $\S 959$ (b) also requires Estate Representatives to follow applicable federal noninsolvency law as well. In re St. Mary Hosp., 86 B.R. 393, 398 (Bankr. E.D. Pa. 1988). Although outside the scope of this Article, by requiring satisfaction of federal non-insolvency law, 28 U.S.C. $\S 959$ (b) also functions as a saving statute for such intra-federal conflict. Indeed, 28 U.S.C. § 959(b) may overcome the doctrine of implied repeal whereby the earlier-enacted statute may be deemed to have been repealed based on Congress's enactment of a subsequent statute that causes an irreconcilable conflict. For a discussion of implied repeal, consider Jesse W. Markham, Jr., The Supreme Court's New Implied Repeal Doctrine: Expanding Judicial Power To Rewrite Legislation Under the Ballooning Conception of "Plain Repugnancy", 45 Gonz. L. REV. 437 (2009).

232 Gillis v. California, 293 U.S. 62, 66 (1934).

233 See Nader v. Allegheny Airlines, Inc., 426 U.S. 290, 299 (1976) (quoting Tex. \& Pac. Ry. v. Abilene Cotton Oil Co., 204 U.S. 426, 446 (1907)).
} 
is a black-letter application of a specific saving clause. By clarifying how 28 U.S.C. $§ 959$ (b) should be interpreted, Gillis set the stage for Midlantic.

\section{B. Midlantic}

Midlantic presented the Supreme Court with an opportunity to set boundaries for both conflict preemption in bankruptcy and 28 U.S.C. $§ 959$ (b). ${ }^{234}$ Instead of seizing the moment, the Court issued what many (including thenJustice William Rehnquist) have characterized as a vague or imprecise opinion that created more questions than it answered. ${ }^{235}$ This critique is correct from some perspectives and may explain courts' unwillingness or inability to formulate a comprehensive framework for conflict preemption. Yet, any comprehensive framework for conflict preemption must incorporate Midlantic's teachings. This subpart describes Midlantic, thereby facilitating its synthesis as part of this Article's framework.

The facts of Midlantic are hardly unique. The debtor, Quanta Resources Corporation, processed waste oil, and the New Jersey Department of Environmental Protection discovered that the debtor had violated its operating permit by accepting oil contaminated with a highly toxic carcinogen. ${ }^{236}$ The debtor initially filed a chapter 11 petition but its case was subsequently converted to chapter 7, and a trustee was appointed. In contravention of New Jersey's environmental laws, the chapter 7 trustee sought to abandon the debtor's contaminated property under 11 U.S.C. $§ 554 .{ }^{237}$ Section 554 allows a trustee to abandon property if it is either (i) burdensome to the estate or (ii) of inconsequential value. ${ }^{238}$ The general effect of abandonment is removal of the property from the debtor's estate. ${ }^{239}$ The removal also eliminates the estate's liability based on continued possession of the property. ${ }^{240}$ Thus, abandonment in the Midlantic case would allow the chapter 7 estate to evade liability for the cleanup of the property. ${ }^{241}$

The Supreme Court relied upon four separate legs as support for precluding the chapter 7 trustee from abandoning the contaminated property: (i)

\footnotetext{
234 As explained below, the Supreme Court found no conflict existed in Midlantic and did not apply the Perez analysis. In re Old Carco L.L.C., 406 B.R. 180, 205 (Bankr. S.D.N.Y. 2009) (evaluating Midlantic Nat'l Bank v. N.J. Dep't of Env't Prot., 474 U.S. 494, 507 (1986)).

235 See Midlantic Nat'l Bank, 474 U.S. at 514 (Rehnquist, J., dissenting).

236 Id. at 494 (majority opinion).

237 Id. at 496-97.

23811 U.S.C.A $\$ 554$ (West 2020).

239 In re Argiannis, 156 B.R. 683, 688 (Bankr. M.D. Fla. 1993).

240 In re Strelsky, 46 B.R. 178, 181 (Bankr. E.D. Va. 1985) (finding that law and equity require liability for post-petition condominium assessments to fall on debtor when property is abandoned to him).

$241 \quad I d$
} 
pre-Code practice, (ii) the limitations on preemption of state law pursuant to 28 U.S.C. § 959(b), (iii) the exception codified under 11 U.S.C. § 362(b)(4), and (iv) the importance of environmental regulation and legislation as illustrated by the then-recent enactment of Comprehensive Environmental Response, Compensation, and Liability Act ("CERCLA"). Collectively, this textual backing confirmed that Congress did not intend for the codification of abandonment to preempt all state laws. ${ }^{242}$

The Court traced the abandonment power to its origins under the 1898 Bankruptcy Act. This earlier version, although uncodified, relied on essentially the same principles as the version enacted as part of the Bankruptcy Code. ${ }^{243}$ The pre-Code version was, however, subject to limitations under state or federal law; ${ }^{244}$ it would yield to a conflict with state or federal law. ${ }^{245}$ Congress never evidenced an intent to eliminate these limitations when it codified the abandonment power. In other words, they were not obstacles to federal interests undergirding the Bankruptcy Code. If they had been, Congress would have expressly eliminated them. In the first example of what became known as the "pre-Code practice" doctrine, ${ }^{246}$ the pre-Code limitations on the abandonment power continued to apply to abandonment power under the Bankruptcy Code. ${ }^{247}$

The Court then articulated further textual evidence for the continued validity of the pre-Code practice. As general support, the Court cited its opinion

\footnotetext{
242 Midlantic Nat'l Bank, 474 U.S. at 507.

243 Ottenheimer v. Whitaker, 198 F.2d 289, 290 (4th Cir. 1952) (explaining that "a trustee in bankruptcy is not compelled to accept property which, in his judgment, is of an onerous and unprofitable nature and would burden rather than benefit the estate").

244 In re Chi. Rapid Transit Co., 129 F.2d 1, 5 (7th Cir. 1942) (stating that even though they are granted the abandonment power, trustees "must comply with valid statutory regulation by the state.”); In re Circle K Corp., No. B-90-5052-PHX-GBN, 1991 WL 349900, at *5 (Bankr. D. Ariz. Apr. 5, 1991) (analyzing Chi. Rapid, 129 F.2d at 5).

245 Ottenheimer, 198 F.2d at 290.

246 United States v. Ron Pair Enters., 489 U.S. 235, 243-46 (1989). The pre-Code practice doctrine can apply when preemption is not implicated and the issue is whether a specific common law practice (irrespective of any conflict with state law) existing under the 1898 Bankruptcy Act survived the enactment of the Bankruptcy Code. See Hartford Underwriters Ins. Co. v. Union Planters Bank, 530 U.S. 1, 11 (2000); United States v. Noland, 517 U.S. 535, 539 (1996); Ron Pair Enters. Inc., 489 U.S. at 243-46. In these cases, the analysis is slightly different than that applied in Midlantic, Kelly, and BFP. When preemption is not implicated, the question is simply whether the current language of the Bankruptcy Code is sufficiently ambiguous to allow for the pre-Code practice to survive. Hartford Underwriters Ins. Co., 530 U.S. at 10. Naturally, no evaluation of the tension between state law and federal law is applicable. Ron Pair Enters., Inc., 489 U.S. at 244. Over time, the Supreme Court has clarified the pre-Code practice must be "sufficiently widespread and well recognized to justify the conclusion of implicit adoption by the Code." Id.

247 The pre-Code practice doctrine is a version of "the canon of statutory construction that Congress is presumed to be aware of judicial interpretations of a statute." NLRB v. Bildisco \& Bildisco, 465 U.S. 513, 524 (1984).
} 
from the prior term in Ohio v. Kovacs, ${ }^{248}$ where it explained that a trustee who sells or abandons property must follow environmental laws and "may not maintain a nuisance, pollute the waters of the State, or refuse to remove the source of such conditions." 249 The Court next explained how the police power exception to the automatic stay (11 U.S.C. § 362(b)(4)) supported a limitation on abandonment power in spite of Congress's failure to enact an analog as a restriction on the abandonment power. ${ }^{250}$ The Court pinpointed the uncertain boundaries of the automatic stay under the 1898 Bankruptcy Act as the reason for Congress's enactment of an express exception to the automatic stay in the Bankruptcy Code. ${ }^{251}$ In contrast, the limitations on the abandonment power were firmly entrenched and did not require codification. ${ }^{252}$

"Title 28 U.S.C. § 959(b) provide[d] additional evidence that Congress did not intend for the Bankruptcy Code to pre-empt all state laws." ${ }^{" 253}$ The Court vaguely summarized:

Even though $\S 959$ (b) does not directly apply to an abandonment under $\S 554(\mathrm{a})$ of the Bankruptcy Code - and therefore does not de-limit the precise conditions on an abandonment - the section nevertheless supports our conclusion that Congress did not intend for the Bankruptcy Code to pre-empt all state laws that otherwise constrain the exercise of a trustee's powers. ${ }^{254}$

As Justice Rehnquist chided, "[t]he precise nature of its indirect application, however, is left unclear." ${ }^{255}$ In spite of this criticism, the Court left the question open and simply highlighted the existence of 28 U.S.C. § 959(b) as further evidence of Congress's intent. In sum, the Court relied upon the pre-Code restrictions on abandonment together with CERCLA, 28 U.S.C. $§ 969$ (b), and 11 U.S.C. § 362(b)(4) to find that the codified abandonment power could be limited by state law. ${ }^{256}$ The Court did not apply an obstacle preemption analysis. ${ }^{257}$

The Court also sought to balance the need to protect public health and safety against Congress's authorization of the abandonment power in bankruptcy

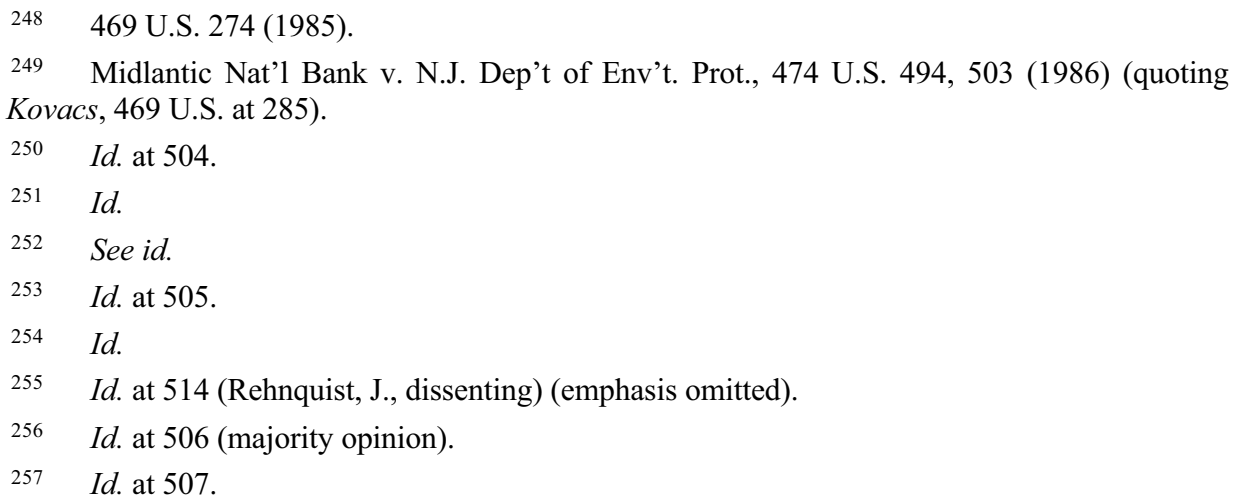


cases. In its holding, the Court precluded bankruptcy courts from "authoriz[ing] an abandonment without formulating conditions that will adequately protect the public's health and safety." ${ }^{258}$ In spite of this broad admonition, the Court concluded its opinion by limiting the reach of its holding in footnote nine:

This exception to the abandonment power vested in the trustee by $\S 554$ is a narrow one. It does not encompass a speculative or indeterminate future violation of such laws that may stem from abandonment. The abandonment power is not to be fettered by laws or regulations not reasonably calculated to protect the public health or safety from imminent and identifiable harm. ${ }^{259}$

This footnote has been roundly interpreted as narrowing the exception to the abandonment power identified by the Midlantic majority. ${ }^{260}$

According to critics, the majority opinion explains little through its vague reasoning and indeterminate holding. ${ }^{261}$ To be sure, courts and commentators have struggled with three fundamental questions left open by the majority: (i) what test applies to the Court's holding? (ii) whether the Court's holding applies to other provisions of the Bankruptcy Code? and (iii) how does 28 U.S.C. § 959(b) fail to "precisely delimit" the abandonment power? Much ink has been spilled over the first issue with a general consensus emerging. The test proposed in this Article builds on the consensus to apply Midlantic's teachings to other provisions of the insolvency law. It further explains why 28 U.S.C. $\S 959$ (b) does not delimit the abandonment power or any other specific insolvency law provision.

Courts formulated various tests to apply the teachings of Midlantic, but "they all use the language quoted from footnote nine."262 Some look beyond

258 Id. at 506-07. This statement conflicts squarely with the Supreme Court's then-recent statements in Ohio v. Kovacs where it stated that

[i]f the site at issue were [debtor's] property, the trustee would shortly determine whether it was of value to the estate. . . If the property were worth less than the cost of cleanup, the trustee would likely abandon it to its prior owner, who would have to comply with the state environmental law to the extent of his or its ability.

469 U.S. 274, 284 n.12 (1985); see also Midlantic Nat'l Bank, 474 U.S. at 509 n.2 (Rehnquist, J., dissenting).

259 Midlantic Nat'l Bank, 474 U.S. at 505 n.9.

260 In re Howard, 533 B.R. 532, 545 (Bankr. S.D. Miss. 2015) ("The majority of Courts that have interpreted footnote nine in Midlantic have held that the 'narrow' exception to a trustee's abandonment power only applies in situations where an imminent and identified harm to the public health and safety exists." (internal citations omitted)).

261 Morris G. Shanker, A Bankruptcy Superfund for Some Super Creditors From Ohio to Midlantic and Beyond, 61 AM. BANKR. L.J. 185, 187-88 (1987).

262 Michael P. Arwood, Trust(ee) and Abandonment Issues: A Proposal for New Action Regarding Abandonment of Environmentally Contaminated Property, 32 EMORY BANKR. DEVS. J. 365, 391 (2016). 
footnote nine and read the tea leaves of the Court's failure to "reach[] the question [of] whether certain state laws imposing conditions on abandonment may be so onerous as to interfere with the bankruptcy adjudication itself." ${ }^{263}$ The Midlantic majority expressly failed to evaluate whether or when state environmental statutes can be sufficiently onerous to trigger this inquiry. Given the lack of validation and example, ${ }^{264}$ it instead should be analyzed as part of whether congressional intent exists to not preempt a particular state law.

The Court also failed to explain if its holding could or should be applied to other insolvency laws. Without further guidance, some courts limit Midlantic's teachings to abandonment and reject its relevance to other Bankruptcy Code provisions such as turnover or lease rejection. ${ }^{265}$ Judge Hughes has already stated the best critique of this position in a different, but analogous, context. In analyzing why the teachings of Stern v. Marshall ${ }^{266}$ should apply outside of the common law counterclaim at issue in that case, ${ }^{267}$ Judge Hughes analogized courts to scientists. ${ }^{268}$ Scientists test hypotheses against laws like gravity that must be followed while courts apply tests against doctrines that must be followed either because they reflect a constitutional principle or they reflect Supreme Court precedent. ${ }^{269}$ Applying this reasoning, courts should evaluate other insolvency provisions under Midlantic's test to determine whether they are subject to the exception to conflict preemption.

Lastly, the evaluation of 28 U.S.C. $\S 959$ (b) has flummoxed many. ${ }^{270}$ What did the Court mean by the fact that the provision did not "precisely delimit" abandonment? The test proposed by this Article slices the Gordian Knot. When abandonment is in direct conflict with state law, as was the case in Midlantic, it

\footnotetext{
263 In re Peerless Plating Co., 70 B.R. 943, 946 (Bankr. W.D. Mich. 1987) (quoting Midlantic Nat'l Bank, 474 U.S. at 507).

264 One court posited a few examples including "one that prohibited abandonment or the closing of at [sic] a case even after an estate was exhausted or one which permitted environmental authorities to completely usurp administration of the case." In re Peerless Plating Co., 70 B.R. at 947 n.3 (internal citations omitted).

265 In re Circle K Corp., No. B-90-5052-PHX-GBN, 1991 WL 349900, at*16 (Bankr. D. Ariz. Apr. 5, 1991) (lease rejection); In re Corona Plastics, Inc., 99 B.R. 231, 235 (Bankr. D.N.J. 1989) (turnover).

266564 U.S. 462 (2011).

267 The counter claim concerned the infamous "broad" versus "narrow" debate regarding what constitutes a Stern claim. See, e.g., Robert Miller, Fleshing Out the Skeleton: Defining the Prongs of Stern v. Marshall, 11 DePAul Bus. \& CoM. L.J. 1, 2 n.6 (2012) (comparing cases under broad versus narrow view).

268 In re Sutton, 470 B.R. 462, 469 (Bankr. W.D. Mich. 2012).

$269 \quad I d$

270 Jill C. Kosmin, Midlantic National Bank v. New Jersey Department of Environmental Protection: Supreme Court Balances Objectives of the Bankruptcy Code and State Environmental Laws, 18 LoY. Univ. CHI. L.J. 1209, 1232 (1987); Paula Thorntib Perkins, Abandonment in the Face of Possible Toxic Contamination: What's a Lender To Do?, 44 Sw. L.J. 1563, 1575 (1991).
} 
is not subject to/precisely delimited by 28 U.S.C. $\S 959($ b). Instead, state law is preempted unless Midlantic's exception is satisfied.

C. Tempnology, L.L.C.

The Supreme Court's recent opinion lends further support for categorizing 28 U.S.C. 959(b) as a specific saving clause. In Tempnology, the debtor moved to reject a non-exclusive license to use the debtor's trademark. ${ }^{271}$ It then filed a declaratory judgment action to confirm that its rejection of the contract also terminated the rights it had granted to the licensee to use the trademark, the functional equivalent of a rescission of the contract. ${ }^{272}$ The Supreme Court acknowledged that the same result as outside of bankruptcy - the licensor's breach of the trademark license does not rescind the right to use the trademark - applies in bankruptcy when the license is rejected (the debtor's rejection is deemed a breach). ${ }^{273}$ Thus, the Court rejected (pun intended) the debtor's assertion that its rejection constituted not only breach but also rescission of the contract. ${ }^{274}$

One of the debtor's primary arguments in favor of rescission focused on how requiring the debtor to continue to follow applicable contract (state law) and trademark law (federal law) would impose an overly onerous burden on reorganizing debtors. ${ }^{275}$ In summarizing weaknesses of the policy underpinnings for this argument, the Court focused on how Congress has decided to balance the interests of federal insolvency law against conflicting law. ${ }^{276}$ "The Code of course aims to make reorganizations possible... [b]ut it does not permit anything and everything that might advance that goal." ${ }^{\text {"277 }}$ In other words, Congress did not intend for obstacle preemption to be applied broadly to facilitate reorganizations, one of Congress's purposes in enacting federal insolvency legislation. This is the result of interpreting 28 U.S.C. 959(b) as a specific preemption clause that defeats obstacle preemption when it is triggered. Next, the Court identified 11 U.S.C. $§ 365$ as a "powerful tool" that affords an Estate Representative the authority to reject an executory contract with the consequence that both the breach and the associated counterparty's claim are both deemed to have arisen pre-petition. ${ }^{278}$ But in allowing rejection of those contractual duties, 11 U.S.C. $\S 365$ does not grant the debtor an exemption from

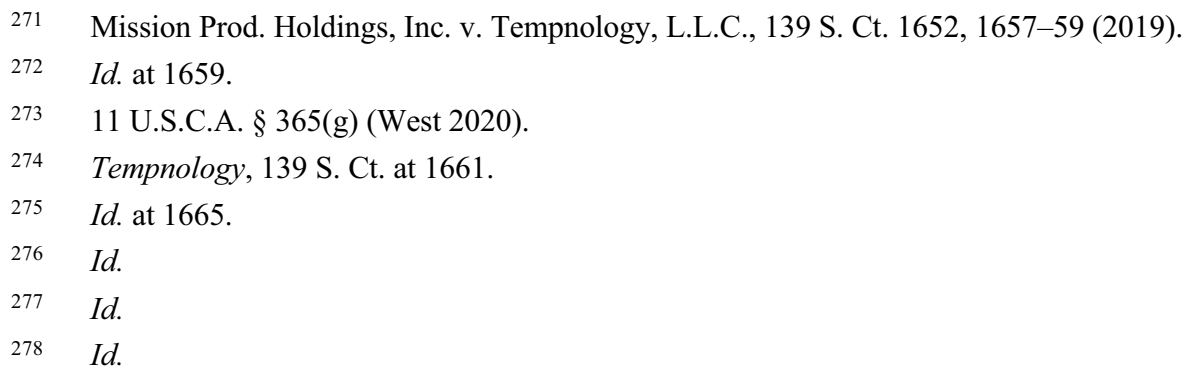


all the burdens that generally applicable law-whether involving contracts or trademarks - imposes on property owners. ${ }^{279}$ Thus, 11 U.S.C. $\S 365$ grants certain powers that trump directly conflicting state contract law by precisely delimiting the effect of rejection. In contrast, it does not immunize an Estate Representative from following state law that is not in direct conflict with federal insolvency law. This is the exact result that follows from interpreting 28 U.S.C. $\S 959$ (b) as a specific saving statute.

\section{PRE-CODE PRACTICES AND CONFLICT PREEMPTION REFINED POST- MIDLANTIC}

The pre-Code practice doctrine is applicable to conflict preemption analysis irrespective of whether 28 U.S.C. $\S 959(\mathrm{~b})$ is triggered. Yet most analyses of it are incomplete as they begin and end with the discussion in Midlantic. ${ }^{280}$ These evaluations ignore two subsequent cases applying the preCode practice doctrine to conflict preemption analyses: Kellyv. Robinson ${ }^{281}$ and BFP v. Resolution Trust Company. ${ }^{282}$ Neither of these cases, however, analyzed whether the applicable state laws were "reasonably calculated to protect the public health or safety from imminent and identifiable harm." 283 This is because they didn't involve any imminent harm to public health or safety. Nevertheless, the Court applied the pre-Code practice doctrine in both instances, and the state laws were not preempted. Given that Kelly and BFP quickly followed Midlantic, footnote nine is unlikely to have been jettisoned or overlooked. The more likely explanation is that this consideration is only applicable when property is being managed or operated by an Estate Representative - the factual scenario in Midlantic but in neither Kelly nor BFP. A brief evaluation of Kelly and BFP is illustrative.

The Supreme Court wasted no time applying the pre-Code practice doctrine following its birth in Midlantic as the Court employed the construct in its next term in Kelly v. Robinson. In Kelly, the Court upheld a state statute requiring a bankruptcy debtor to pay criminal restitution fees to a state in spite of obtaining a discharge. ${ }^{284}$ This conclusion was surprisingly not only based on the holding of Perez but also the expansive definition of "debt" under the Bankruptcy Code: liability on a claim. ${ }^{285}$ The latter is particularly strong

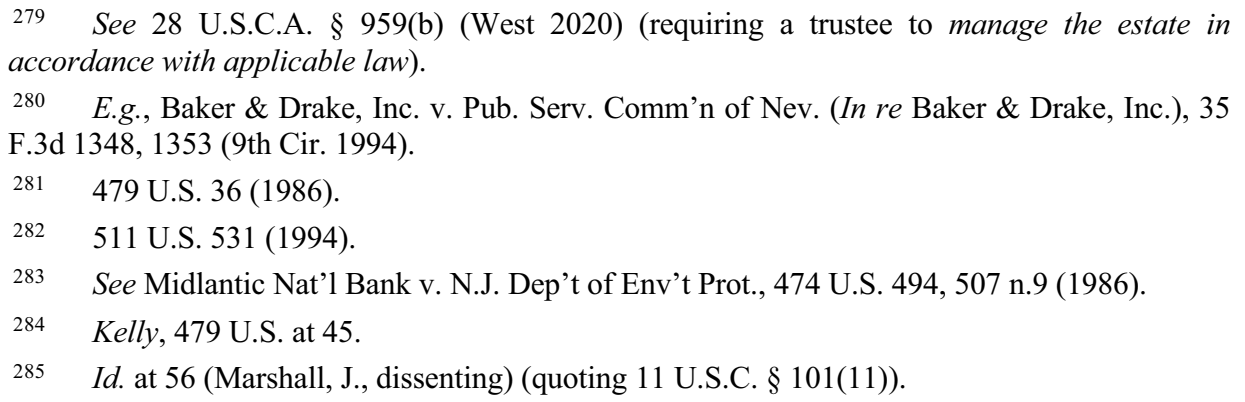


evidence of congressional intent as the Bankruptcy Code's definition of debt was much broader than the prior definition under the 1898 Bankruptcy Act. The majority countered by resorting to a historical analysis. Even under the 1898 Bankruptcy Act, the definition of debt could have included restitution obligations. Yet, courts roundly excepted them, as recognized by leading commentators at the time of the Bankruptcy Code's enactment. ${ }^{286}$ This "established judicial exception" was also supported by the traditional role states play in criminal prosecutions and penal sanctions. ${ }^{287}$ Quoting Justice Frankfurter's evaluation of conflict preemption when federal regulations and historic state law collide, the Court concluded that absent greater specificity, insufficient evidence of Congress' intent to alter the historical treatment of criminal restitution sanctions existed. ${ }^{288}$ Sub silentio, the historical exception to discharge, eliminated the concern that the judicially constructed exception constituted an obstacle to Congressional intent.

What was implicit in Kelly was made explicit in BFP v. Resolution Trust $C_{0}{ }^{289}$ The potential conflict in $B F P$ arose between state foreclosure law that would set aside a sale if it is "grossly inadequate" and federal fraudulent transfer law that avoids a constructive fraudulent transfer that is made for less than "reasonably equivalent value." 290 Could a foreclosure sale conducted in accordance with state law still be avoided as a fraudulent transfer? The majority reasoned that Congress could "disrupt the ancient harmony that foreclosure law and fraudulent conveyance law, those two pillars of debtor-creditor jurisprudence, have heretofore enjoyed. But absent clearer textual guidance than the phrase 'reasonably equivalent value' - a phrase entirely compatible with preexisting practice - we will not presume such a radical departure." ${ }^{, 291}$ Prior to the enactment of the Bankruptcy Code, the Court asserted that no court "had ever applied the 'grossly inadequate price' badge of fraud under fraudulent transfer law to set aside a foreclosure sale." ${ }^{292}$ As further support for the pre-Code practice doctrine, the majority relied upon the reasoning from Kelly and Justice Frankfurter's characterization of the relationship between federal statutes and historical state laws. ${ }^{293}$ The essential state interest in "the general welfare of society is involved in the security of the titles to real estate and the power to

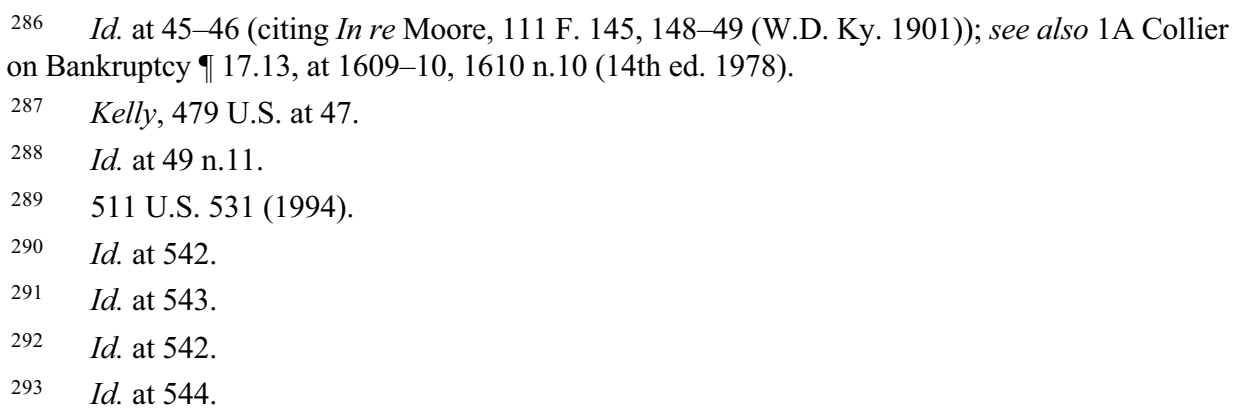


ensure that security inheres in the very nature of state government." ${ }^{, 294}$ Given its importance, a clear manifest intent was necessary for the Bankruptcy Code to displace state foreclosure laws. ${ }^{295}$

Justice David Souter's dissent criticized the majority's failure to evaluate obstacle preemption. Preempting state law and avoiding foreclosures that constituted transfers for "less than reasonably equivalent value" would be consistent with "a maximum and equitable distribution for creditors," a universally recognized goal of the Bankruptcy Code. ${ }^{296}$ The dissent concluded by citing other examples where bankruptcy law's substantive provisions trumped state law, including the power to reject executory contracts. ${ }^{297}$

Contrary to the dissent in $B F P$, the pre-Code practice doctrine is conformable with the underlying reasoning of obstacle preemption. If a widespread judicial practice based on a significant state law limitation existed before the enactment of the Bankruptcy Code, a failure to expressly disavow the practice signals that the practice is not an obstacle to Congress's intent. That is exactly the point of Midlantic and its progeny. Going down the rabbit hole of obstacle preemption is unnecessary when a pre-Code practice signals Congress's determination that no obstacle exists. ${ }^{298}$

An important distinction between Midlantic on the one hand, and Kelly and $B F P$ on the other, is the applicability of the imminent and identifiable harm limitation to the pre-Code practice doctrine. Notice there was no discussion in Kelly or $B F P$ of whether discharging restitution debts or facilitating mortgage foreclosure sales was "reasonably calculated to protect the public health or safety from imminent and identifiable harm." ${ }^{.299}$ Instead, recognition of the historical exceptions and their importance was sufficient to eliminate conflict preemption. Why the discrepancy? Of course, one answer is that Kelly and BFP implicitly overruled the limitation recognized by Midlantic. Given the closeness in time between the opinions and their citations to Midlantic without disavowal, it is doubtful that the Supreme Court intended to discard its limitation. The probable answer is that the Supreme Court wanted cases similar to Midlantic to hinge on the immediacy of the potential harm. In contrast, the facts of Kelly and BFP did not warrant these extra protections. When property is not being operated or

\footnotetext{
294 Id. (internal quotations and citations omitted).

295 Id. at 544-45; see also Title Max v. Northington (In re Northington), 876 F.3d 1302, 1312-

13 (11th Cir. 2017) (applying BFP to state regulation of pawn shops).

296 BFP, 511 U.S. at 563, 569 (Souter, J., dissenting).

$297 \quad I d$. at 569 (internal citations omitted).

298 Midlantic Nat'l Bank v. N.J. Dep't of Env't Protection, 474 U.S. 494, 506 (1986) ("[W]ithout reaching the question whether certain state laws imposing conditions on abandonment may be so onerous as to interfere with the bankruptcy adjudication itself, we hold that a trustee may not abandon property in contravention of a state statute or regulation that is reasonably designed to protect the public health or safety from identified hazards.").

$299 \quad$ Id. at 507 n.9.
} 
managed (like in Kelly and $B F P$ ), it is doubtful that the threat to public safety and health will be imminent. Conversely, when an Estate Representative is operating or managing property, imminent public health and safety concerns are often present. Thus, Midlantic's further limitation on the pre-Code practice doctrine appears to be only applicable when an Estate Representative is operating or managing property in its possession.

\section{PROPOSED TEST FOR CONFLICT PREEMPTION}

Crafting a test for conflict preemption that is faithful to Midlantic's and Gillis's treatment of 28 U.S.C. $\S 959$ (b), the pre-Code practice doctrine, and the general rule of Perez is challenging. Unfortunately, the Supreme Court has not provided further guidance and has left lower courts to construct a test. No court or commentator has attempted to fill the void by proposing a usable framework. ${ }^{300}$ This Article fills this void through the following bifurcated framework:

(I) When 28 U.S.C. § 959(b) is not triggered:

a. In bankruptcy or a receivership governed by bankruptcy law, the traditional conflict preemption analysis applies, ${ }^{301}$ unless a historical practice exists excepting the conflicting state law from preemption, ${ }^{302}$ or

b. In a non-bankruptcy law governed receivership, the traditional determination of whether a uniform federal common law governs unless a historical practice incorporating state law applies.

(II) When 28 U.S.C. $\S 959$ (b) is triggered, a state law governing the management or operation of property

a. is not preempted or is incorporated as the federal common law rule when the property is being managed or operated

(i) in the ordinary course, ${ }^{303}$ or

\footnotetext{
300 To its credit, the Bankruptcy Court for the Southern District of New York has recognized three of the inputs to construct a coherent test: Perez, Midlantic, and 28 U.S.C. § 959(b). See In re Old Carco L.L.C., 406 B.R. 180, 201-04 (Bankr. S.D.N.Y. 2009).

301 Hillsborough Cnty. v. Automated Med. Lab'ys, Inc., 471 U.S. 707, 713 (1985).

302 See BFP, 511 U.S. at 540-43; Kelly v. Robinson, 479 U.S. 36, $44-47$ (1986).

303 Gillis v. California, 293 U.S. 62, 65 (1934); Ky. Emps. Ret. Sys. v. Seven Cntys. Servs., Inc., 823 F. App'x 300, 305 (6th Cir. 2020).
} 
(ii) pursuant to 11 U.S.C. $\S 363$ (b) or an equivalent receivership law or rule. ${ }^{304}$

b. is preempted or a uniform federal common law rule applies when an insolvency law or federal interest precisely delimits operation or management, ${ }^{305}$ unless

(i) a historical practice exists to support excepting the state law from conflict preemption or a uniform federal common law rule; $;^{306}$

(ii) the state law is "reasonably designed to protect the public health or safety from identified hazards"; and

(iii) an "imminent and identifiable harm" exists. ${ }^{307}$

This test is perhaps better shown (especially for visual learners) in the diagram below:

\footnotetext{
304 E.g., Calvert v. Bongards Creameries (In re Schauer), 835 F.2d 1222, 1225 (8th Cir. 1987).

305 Midlantic Nat'l Bank v. N.J. Dep't of Env't Prot., 474 U.S. 494, 501 (1986).

306 This intent usually takes the form of the pre-Code Practices Doctrine but can also be signaled by federal legislation reflecting similar priorities to the relevant state legislation.

307 Midlantic Nat'l Bank, 474 U.S. at 506-07, 507 n.9.
} 


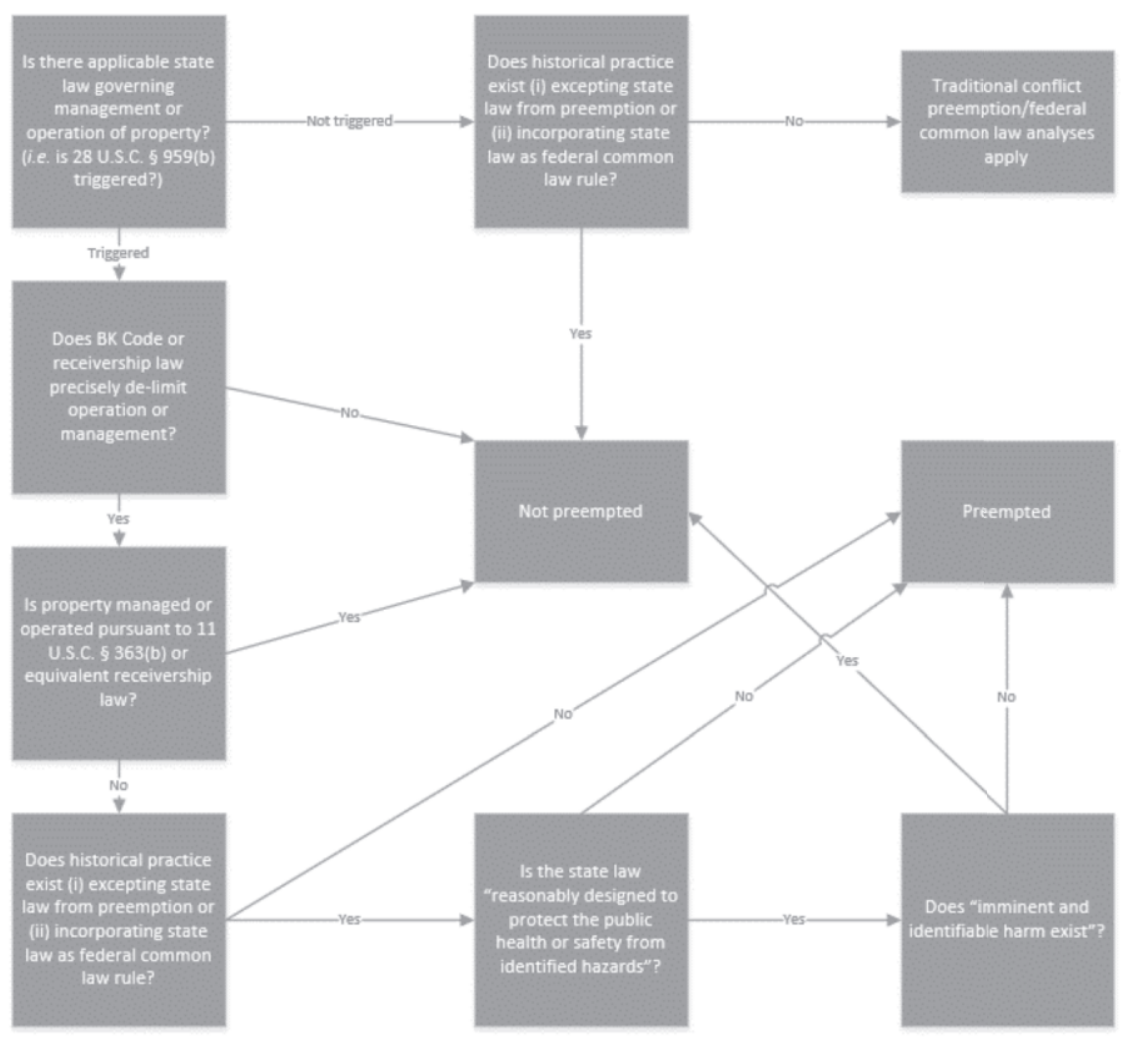

If property of the estate is not being managed or operated by an Estate Representative, the first prong of the framework applies, and general preemption or federal common law principles govern the conflict preemption analysis. ${ }^{308}$ The exception to these traditional evaluations arises when a historical practice exists. Pinpointing whether an exception applies requires following the blueprint set forth in Kelly and BFP: was there a pre-existing practice sufficiently recognized at the time of the enactment of the Bankruptcy Code or Rule 66 to support an inference that Congress did not intend to displace it?

If the property of the estate is being managed or operated by an Estate Representative, then the second prong of the test is triggered. Besides confirming the necessity of an Estate Representative following applicable state law, 28 U.S.C. $§ 959$ (b) also eliminates the usual conflict preemption and federal

308 As the Supreme Court observed in Perez v. Campbell, no reason exists for creating a subject standard for obstacle preemption in bankruptcy proceedings. This is equally true regarding receiverships. 
common law analyses. Gillis v. State of California made this rule plain. ${ }^{309}$ When an Estate Representative is operating or managing property in ordinary course, without need to resort to any federal insolvency law (like the receiver in Gillis), no conflict exists. Returning to our initial examples recited in the introduction, a landlord - debtor cannot escape a local rent control ordinance simply because it makes reorganization more challenging. ${ }^{310}$ In a bankruptcy case, the impossibility branch does not apply because there is no applicable federal statute, while 28 U.S.C. $\S 959$ (b) eliminates obstacle preemption and requires the compliance with state law. In a receivership, the state law will be incorporated as the federal common law rule, notwithstanding any obstacle the state law presents to federal interests.

The same result occurs when an Estate Representative is using, selling, or leasing property outside the ordinary course under 11 U.S.C. $\S 363(b)$ or equivalent receivership law. Section 363(b) is an enabling statute whereby the same restrictions that exist outside of a bankruptcy case under state law remain applicable without alteration. ${ }^{311}$ The Estate Representative succeeds to only the rights the debtor would have enjoyed pre-petition. ${ }^{312}$ She retains the same rights to dispose of property as the debtor would have outside of bankruptcy, no more and no less. ${ }^{313}$ For example, accompanying state law remains applicable when a debtor conducts a going-out-of-business sale pursuant to 11 U.S.C. $\S 363(b) .^{314}$ State law requirements for such sales, including an application process providing a detailed inventory of goods and limitations on the replenishment of inventory, cannot be evaded because they are incorporated as the rule of decision by 11 U.S.C. $§ 363\left(\right.$ b). ${ }^{315}$ Because federal law has substantively adopted state law in this situation, no conflict exists. ${ }^{316}$

\footnotetext{
309 Gillis v. California, 293 U.S. 62, 65 (1934).

310 In re Friarton Ests. Corp., 65 B.R. 586, 589-90 (Bankr. S.D.N.Y. 1986); cf. In re Vel Rey Props., Inc., 174 B.R. 859, 864 (Bankr. D.D.C. 1994) (denying trustee's motion to operate apartment building in violation of local ordinances).

311 Integrated Sols., Inc. v. Serv. Support Specialties, Inc., 124 F.3d 487, 494 (3d Cir. 1997); Calvert v. Bongards Creameries (In re Schauer), 835 F.2d 1222, 1225 (8th Cir. 1987); SEC v. First Choice Mgmt. Servs., Inc., No. 3:00-CV-446-RM, 2010 WL 148313, at *8 (N.D. Ind. Jan. 12, 2010); $c f$. In re Jackus, 442 B.R. 365, 369-70 (Bankr. D.N.J. 2011) (state law limitation on sale of annuity); In re White Crane Trading Co., Inc., 170 B.R. 694, 702 (Bankr. E.D. Cal. 1994) (state law limitation on going-out-of-business sale).

312 Integrated Sols., Inc., 124 F.3d at 492.

$313 \quad$ Id. at 494.

314 In re Crawford Furniture Mfg. Corp., 460 B.R. 586, 589 (Bankr. W.D.N.Y. 2011).

$315 \quad$ Id

316 The other subsections of 11 U.S.C. $\$ 363$ grant greater rights than would be available outside of bankruptcy and, as a result, do not simply enable state law. See Trevor W. Swett III, "Free and Clear" Bankruptcy Sale Orders and State Law Successor Liability Claims: The Overlooked
} 
When the federal insolvency law alters the status quo by precisely delimiting the conditions for management or operation, state law rights may be preempted or a uniform federal common law imposed. The paradigmatic example is the rejection of an executory contract. Although rejection of an executory contract is judged by the same legal standard as a sale outside the ordinary course of business - the business judgment rule-11 U.S.C. $§ 365$ (and federal common law in the case of receiverships) substantively alters underlying state law rights by delimiting the precise conditions for rejection. ${ }^{317}$ In the case of rejection, a historical exception exists similar to the one identified for abandonment. ${ }^{318}$ If the state law is reasonably calculated to protect the public health or safety from an imminent and identifiable harm, the state law will not be preempted. ${ }^{319}$ Just like the abandonment power evaluated in Midlantic, rejection is not governed by 28 U.S.C. $\S 959($ b). Because a direct conflict exists,

Question of Preemption, 25 AM. BANKR. INST. L. REV. 275, 288 (2017) (explaining that 11 U.S.C. $\S 363(\mathrm{f})(3)$ will allow the sale of property when the value is greater than the sum of the liens secured to the property even if the sale would otherwise be precluded by non-bankruptcy law).

317 Rubloff Dev. Grp., Inc. v. Kmart Corp., 389 B.R. 555, 561 (N.D. Ill. 2008) ("[G]eneral principles governing contractual benefits and burdens do not always apply in the bankruptcy context." (quoting Data-Link Sys., Inc. v. Whitcomb \& Keller Mortg. Co., 715 F.2d 375, 379 (7th Cir. 1983))); In re Old Carco L.L.C., 406 B.R. 180, 203 (Bankr. S.D.N.Y. 2009); see also In re Circle K Corp., No. B-90-5052-PHX-GBN, 1991 WL 349900, at*15 (Bankr. D. Ariz. Apr. 5, 1991). More specifically, the rejection relieves the rejecting party of the duty of future performance. Mission Prod. Holdings, Inc. v. Tempnology, L.L.C., 139 S. Ct. 1652, 1658 (2019); Taylor-Wharton Int'l L.L.C. v. Blasingame (In re Taylor-Wharton Int'l L.L.C.), No. 09-14089 BLS, 2010 WL 4862723, at*3 (Bankr. D. Del. Nov. 23, 2010). This is not the case for an anticipatory repudiation (the non-bankruptcy analog), whereby the non-repudiating party may continue to treat the contract as valid until the time of performance arises. Coventry Enters. L.L.C. v. Sanomedics Int'l Holdings, Inc., 191 F. Supp. 3d 312, 320 (S.D.N.Y. 2016). Moreover, 11 U.S.C. $\$ 365(\mathrm{~g})$ deems the lease rejection to have occurred as of the petition date, another alteration from non-bankruptcy law. In re Kmart Corp., No. 02 B 2474, 2007 WL 4556991, at *7 (Bankr. N.D. Ill. Nov. 20, 2007). Federal common law treats executory contracts in receiverships similarly, including the concept of rejection relating back to the order of receivership. See Pa. Steel Co. v. N.Y.C. Ry. Co., 198 F. 721, 744 (2d Cir. 1912); Janvey v. Alguire, No. 3:09-CV-0724-N, 2014 WL 12654910, at *7 (N.D. Tex. July 30, 2014).

318 Midlantic Nat'l Bank v. N.J. Dep't of Env’t Prot., 474 U.S. 494, 516 (1986) (relying on In re Chi. Rapid Transit Co., 129 F.2d 1, 5 (7th Cir. 1942), and equating rejection with abandonment). 319 See In re Baker \& Drake, Inc., No. BK-N-91-00614, 1992 WL 682764, at *3 (D. Nev. Oct. 22, 1992), aff'd, 35 F.3d 1348 (9th Cir. 1994) ("This court finds nothing in the Bankruptcy Code which grants the authority to the bankruptcy court to authorize acts in contravention of a state statute or regulation that is reasonably necessary to protect the public health or safety from identified hazards."). This is not to say this test is always easy to apply. The exact parameters of "reasonably designed to protect the public health or safety from identified hazards" and an "imminent and identifiable harm" are difficult to discern. Midlantic Nat'l Bank, 474 U.S. at 516 (Rehnquist, J., dissenting) (criticizing the majority's failure to identify or give examples of laws that would be sufficient for the exception to the law at issue in the case). 
it renders 28 U.S.C. $§ 959$ (b)'s status as a specific saving clause inapplicable. ${ }^{320}$ Accordingly, the applicable state law is subject to preemption unless the exception outlined in Midlantic applies. ${ }^{321}$

The addition to the test of an inquiry based on Midlantic footnote nine not only follows Supreme Court precedent, but it also represents the need to balance between (i) the importance of the certainty provided by the insolvency law when an Estate Representative is managing or operating property and (ii) the need for a pressure release valve when the risk to the public is obvious and immediate. Although prone to over-use, the "melting ice cube" analogy is often apt. ${ }^{322}$ Estate Representatives must frequently make decisions quickly to preserve value for creditors, even if the decision is subject to approval by a federal court. Knowing that a federal statute or rule prescribes the legal standard provides the Estate Representative, and any affected parties-in-interest, with greater guidance and predictability in an urgent situation. In contrast, when the potential public harm is clear and looming, such concerns should trump the interest of certainty.

Consider the final two examples from the introduction. When a state statute places limitations on an automakers' authority to terminate dealership leases by establishing waiting and notice periods, it directly conflicts with the federally recognized authority to reject unexpired leases. Because no imminent threat to public safety and health exists, the state laws are preempted. ${ }^{323}$ Change the hypothetical to a debtor that operates a coal mine and attempts to reject a lease for land it operated without fulfilling its reclamation obligations and the opposite result is likely. The Midlantic exception to preemption should be triggered as the failure to treat the water and resurface the land will have significant and immediate adverse impacts on public health and safety.

\section{UNCERTAIN BOUNDARIES OF 28 U.S.C. § 959(B)}

Section 959(b) itself would be of little value if the statute cannot be enforced. Congress did not specify an enforcement mechanism in 28 U.S.C. $\S 959$ (b). Such an omission begs the question: Does 28 U.S.C. $\S 959$ (b) have any teeth? Judicial interpretation has granted it sharp fangs.

\footnotetext{
320 See In re Old Carco L.L.C., 406 B.R. at 212 n.32; ETS Payphones, Inc. v. AT\&T Universal Card (In re PSA, Inc.), 335 B.R. 580, 587 (Bankr. D. Del. 2005) ("Section 959(b) does not stand for the proposition advanced by Citi, that the state law protections provided by the state of Georgia can be used to negate ETS' avoiding powers under $\S 549$ and $\S 550$ of the Code. The requirement that the debtor in possession continue to operate according to state law requirements imposed on the debtor in possession (i.e., $\S 959$ (b)) does not imply that its powers under the Code are subject to the state law protections provided to the creditor.").

321 In re Old Carco L.L.C., 406 B.R. at 204.

322 See Jacoby \& Janger, supra note 9, at 865-66 (discussing the use of the "melting ice cube" as justification for quick sales pursuant to 11 U.S.C. § 363).

323 In re Old Carco L.L.C., 406 B.R. at 204.
} 
Penalties, fines, or other expenses incurred to remedy violations are entitled to administrative expense priority, ${ }^{324}$ i.e. payment pari passu with estate professionals and, in the case of a reorganization, payment in full, in cash, upon confirmation of a plan. ${ }^{325}$ Thus, debtors, trustees, and unsecured creditors' committees often fight fiercely to cabin 28 U.S.C. $\S 959$ (b) in every way possible. Their efforts have led some courts to erroneously restrict the reach of 28 U.S.C. $\S 959$ (b), resulting in the current circuit split.

The usefulness of the test proposed in this Article is limited if the boundaries of 28 U.S.C. $\S 959$ (b) remain uncertain. In evaluating the reach of 28 U.S.C. $\S 959$ (b), the majority of courts have distinguished between liquidating Estate Representatives and operating Estate Representatives by forcing the latter to comply with applicable state laws while immunizing the former. Although some courts have treated liquidating Estate Representatives and operating Estate Representatives equivalently (the correct result), they have failed to draw the logical link with 28 U.S.C. $§ 960$. Indeed, 28 U.S.C. $§ 960$, a statute with the same purpose as 28 U.S.C. $\S 959$ (a), was once the subject of the exact same split, at least until the Supreme Court brought clarity in California Equalization Board

\footnotetext{
324 Texas v. Lowe (In re H.L.S. Energy Co., Inc.), 151 F.3d 434, 438-39 (5th Cir. 1998); Ala. Surface Mining Comm'n v. N.P. Mining Co., Inc. (In re N.P. Mining Co., Inc.), 963 F.2d 1449, 1457-59 (11th Cir. 1992). This case line originated from the broader holding of Reading Co. $v$. Brown, where the Supreme Court evaluated the standard for administrative expenses under the 1898 Bankruptcy Act and adopted an expansive interpretation of what is an "actual, necessary cost" entitled to priority by holding that damages in negligence to a third party arising out of the receiver's administration of the estate give rise to an "actual and necessary cost." 391 U.S. 471, 485 (1968). "It is theoretically sounder ... to treat tort claims arising during [a bankruptcy] arrangement as actual and necessary expenses of the arrangement rather than debts of the bankrupt." Id. at 483. Other courts have even suggested that a higher priority, even above secured creditors, may be appropriate when the costs are associated with remedying an imminent risk of harm to public health (i.e. satisfaction of the exception to preemption outlined in Midlantic). Many courts have extended administrative priority claims to post-petition actions to remedy prepetition violations of environmental law rather than just cabining the administrative priority to violations that arose post-petition. See Boyd v. Dock’s Corner Assocs. (In re Great N. Forest Prod., Inc.), 135 B.R. 46, 61 (Bankr. W.D. Mich. 1991) (listing cases). Other cases have even elevated claims for remedying environmental cleanup above secured claims if the costs are associated with mitigating a risk to imminent harm to public health. In re Pierce Coal \& Const., Inc., 65 B.R. 521, 531 (Bankr. N.D.W. Va. 1986); cf. In re Quanta Res. Corp., 739 F.2d 912, 922 n.11 (3d Cir. 1984) (suggesting that elevating environmental claims above secured claims would not constitute a taking of the secured creditor's property under the Fifth Amendment to the Constitution); Minn. Pollution Control Agency v. Gouveia (In re Globe Bldg. Materials, Inc.), 345 B.R. 619, 636 (Bankr. N.D. Ind. 2006) (explaining that the Supreme Court in Midlantic "in essence created a class of "ordinary and necessary' Chapter 7 administration expense which supersedes and primes expenses of administration under 11 U.S.C. § 503(b)" and all unsecured creditors).

32511 U.S.C.A. § 503(b)(2) (West 2020) (categorizing compensation and reimbursement of estate professionals under 11 U.S.C. $§ 330$ as administrative expenses); id. § 1129(a)(9) (requiring payment of all administrative expenses in full upon the effective date of a confirmed plan unless otherwise agreed).
} 
v. Sierra Summit, Inc. ${ }^{326}$ The parallels between the pre-Sierra Summit split regarding 28 U.S.C. $\S 960$ (a) and the current split over 28 U.S.C. $§ 959$ (a) are not just telling, they are conclusive. Section 959(b) applies equally to liquidating and operating Estate Representatives.

\section{A. Origin of Liquidating/Operating Distinction and Uncertainty on the} Scope of the 28 U.S.C. $\$ 959(b)$

Palmer v. Webster \& Atlas National Bank of Boston ${ }^{327}$ is the starting point for analyzing the circuit split concerning the application of 28 U.S.C. $§ 959$ (b). ${ }^{328}$ Subsequent analysis of its dicta birthed the erroneous view that "manage and operate" does not apply to liquidating Estate Representatives. In Palmer, the issue presented was whether an operating trustee who rejected a lease was still required to pay applicable state taxes and post a bond required by state law. ${ }^{329}$ As background, the Court explained that the purpose of the predecessors of 28 U.S.C. $\S 959$ (b) and $\S 960$ was to dispel the idea that an Estate Representative "could ignore the rules of law of the state of operation affecting the conduct of the business committed to his charge." 330 To clarify, the Court in Palmer analyzed the actions of a trustee operating a reorganizing debtor, where no hint of liquidation was present. ${ }^{331}$ The use of the term "operate" was merely descriptive of the current state of facts for that case, not a blanket statement that non-operating estates did not have to comply with applicable state law. However, in the years after Palmer, courts latched onto the above-quoted language from Palmer and exempted liquidating trustees from satisfying 28 U.S.C. $§ 959(b) .^{332}$

\footnotetext{
326490 U.S. 844 (1989).

$327 \quad 312$ U.S. $156(1941)$.

$328 \quad I d$.

329 Id. at 166.

330 Id. Although the case dealt with taxes, which were governed by the predecessor to 28 U.S.C. $\S 960$ (a), the Supreme Court cited cases evaluating the predecessor to 28 U.S.C. $§ 959$ (b) in support of this dicta. $I d$. at 166 n. 15 .

331 Id. at $157-58$.

332 See, e.g., In re Borne Chem. Co., Inc., 54 B.R. 126, 135 (Bankr. D.N.J. 1984). The other front of support for this view was the Second Circuit's dicta in the footnote of a per curium opinion. Sarf v. N.Y. Dep't of Health (In re Adelphi Hosp. Corp.), 579 F.2d 726, 729, n.6 (2d Cir. 1978) ("[A] trustee in bankruptcy is in no sense a manager of an institution's operations."). This statement conflates manager and operator when the two are separate statuses both governed by the statute. See supra note 299 and accompanying text. The court also went on to explain that the state statute was in conflict with the trustee's abandonment power under the Bankruptcy Act and was, as a result, preempted. $I d$. at 729. Courts were not unanimous, however. See United States v. Schroeder, 204 F. Supp. 199, 204 (S.D. Iowa 1962) (liquidating receiver's actions were governed by 28 U.S.C. $\S 959(b))$.
} 
Courts also mistook an absence of case law applying 28 U.S.C. $\S 959$ (b) to liquidating Estate Representatives to signify an exception. ${ }^{33}$

\section{B. Midlantic Leaves the Issue Unresolved}

Midlantic presented the Supreme Court with the chance to banish any distinction between the treatment of liquidating and operating Estate Representatives and delineate the scope of 28 U.S.C. $\S 959$ (b). Instead of grasping this opportunity, it created more questions than it answered. Setting the stage for the Supreme Court, the Third Circuit majority held that 28 U.S.C. $\S$ 959(b) applies to liquidating Estate Representatives as management of the debtor's property includes both liquidation and abandonment. ${ }^{334}$ Judge Gibbons' dissent took the opposite perspective and suggested that 28 U.S.C. § 959(b) did not apply to liquidation proceedings. ${ }^{335}$

The Supreme Court even teed up the issue: "Petitioners have contended that $\S 959$ (b) is relevant only when the trustee is actually operating the business of the debtor, and not when he is liquidating it." 336 At this point, the Court could have eliminated any confusion surrounding the boundaries of 28 U.S.C. $§ 959$ (b) by affirming or reversing the Third Circuit's holding. ${ }^{337}$ Instead, the Court declined to directly address the boundaries of 28 U.S.C. $\$ 959$ (b). ${ }^{338}$ As discussed previously, the Court found that the statute did not precisely apply to abandonment under 11 U.S.C. $§ 554 .{ }^{339}$ Rather, its existence was relevant to whether Congress intended to preempt state laws by enacting 11 U.S.C. $\S 554 .^{340}$ Unlike the majority in Midlantic, the dissent, authored by Justice Rehnquist, was not oblique. ${ }^{341}$ It characterized the majority's "discussion of 28 U.S.C. $§ 959$ (b) [as] somewhat difficult to fathom." "342 Abandonment simply did not constitute management or operation under 28 U.S.C. $\S 959($ b) as it would "strain the language of $\S 959$ (b)." ${ }^{343}$ The only support mustered for this statement was a Second Circuit case that classified a liquidating trustee as "in no sense a manager

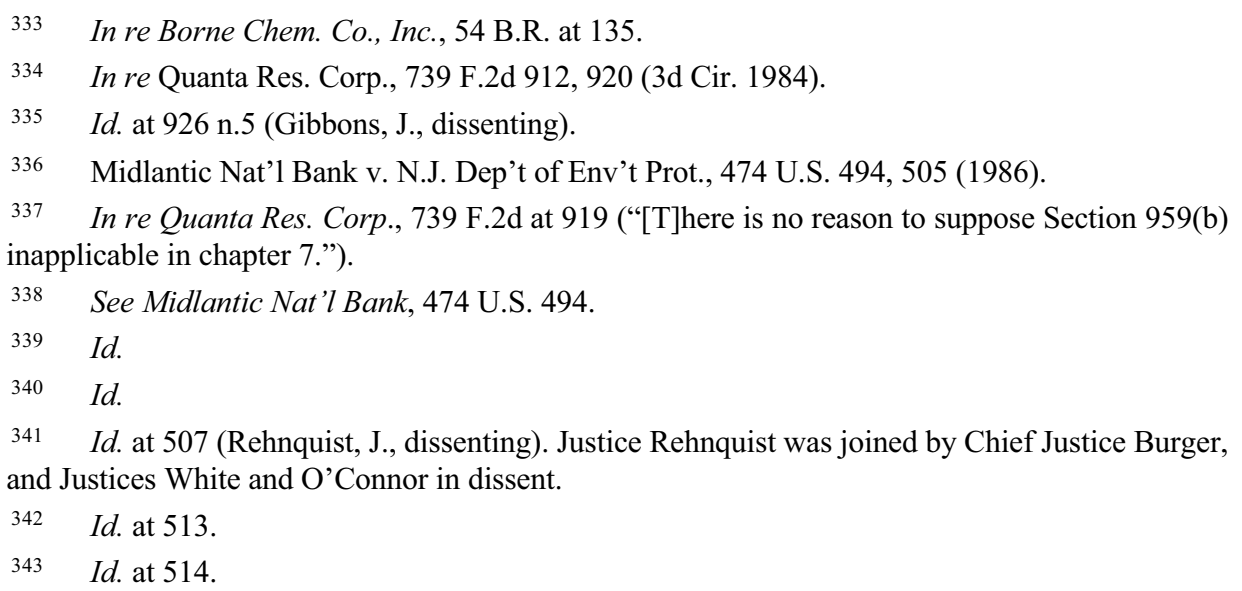


of an institution's operations." 344 This quote does not properly evaluate 28 U.S.C. $\S 959$ (b) as the terms "manage" and "operate" modify the word "property," not each other. When improperly read in this way, the statute is inappropriately cabined.

\section{A Majority View Built on Shaky Foundations}

Following Midlantic, courts predictably struggled with whether 28 U.S.C. § 959(b) applied to liquidating Estate Representatives. The majority of courts (in both bankruptcies and receiverships) have exempted liquidating Estate Representatives from 28 U.S.C. $§ 959(b) .{ }^{345}$ Some of these courts found that the Midlantic majority itself was supportive of the distinction between liquidating and operating Estate Representatives. ${ }^{346}$ Any reference to actual language used by the majority is conspicuously lacking. Other courts have cited Justice Rehnquist's dissent as authoritative. ${ }^{347}$

Cases also began to rely upon the predecessor to 28 U.S.C. $\S 959$ (a) for further support. This subsection is a codification of the Barton Rule, which originated in Barton v. Barbour, ${ }^{348}$ and requires an entity to obtain permission from the appointing court prior to suing Estate Representatives for "any of their acts or transactions in carrying on business connected with such property." 349 In the seminal case evaluating 28 U.S.C. $\$ 959\left(\right.$ a), Vass v. Conron Brothers Co.,${ }^{350}$ the Second Circuit outlined the breadth of the predecessor to 28 U.S.C. § 959(a) (which uses the same relevant language as the modern successor). ${ }^{351}$ Judge Learned Hand's opinion held that the provision did not apply to Estate Representatives who seek "[m]erely to hold matters in status quo; to mark time, as it were; to do only what is necessary to hold the assets intact; such activities

\footnotetext{
344 Id. (citing Sarf v. N.Y. Dep’t of Health (In re Adelphi Hosp. Corp.), 579 F.2d 726, 729 n.6 (2d Cir. 1978)).

345 E.g., SEC v. Wealth Mgmt. L.L.C., 628 F.3d 323, 334 (7th Cir. 2010) ("Modern courts have ... concluded that $\S 959$ (b) does not apply to liquidations." (internal citations omitted)); In re Corona Plastics, Inc., 99 B.R. 231, 236 (Bankr. D.N.J. 1989); Walker v. Maury Cnty. (In re Scott Hous. Sys., Inc.), 91 B.R. 190, 196 (Bankr. S.D. Ga. 1988).

346 Saravia v. 1736 18th St., N.W., Ltd. P'ship, 844 F.2d 823, 827 (D.C. Cir. 1988); Walsh v. West Virginia (In re Sec. Gas \& Oil, Inc.), 70 B.R. 786, 796 (Bankr. N.D. Cal. 1987). The District of Columbia Circuit even used this alleged distinction to explain why 28 U.S.C. § 959(b) did not "precisely delimit" abandonment by a liquidating trustee. Saravia, 844 F.2d at 827; see also In re St. Lawrence Corp., 239 B.R. 720, 726 (Bankr. D.N.J. 1999), aff'd, 248 B.R. 734 (D.N.J. 2000).

$347 \quad$ In re Walker, 91 B.R. at 195.

348104 U.S. 126 (1881).

349 Vass v. Conron Brothers Co., 59 F.2d 969, 971 (2d Cir. 1932) (explaining the relationship between the predecessor to 28 U.S.C. $\S 959$ (a) and Barton).

$350 \quad 59$ F.2d 969 (2d Cir. 1932).

$351 \quad I d$. at 971 .
} 
do not seem to us to be a continuance of the business." 352 To be sure, Judge Hand did not link 28 U.S.C. $§ 959$ (a) to 28 U.S.C. $§ 959$ (b), only the former was analyzed. ${ }^{353}$ The two subsections have different goals and they use different terms - "carrying on business" compared to "managing and operating property." Only later did courts equate these two subsections. ${ }^{354}$

The final alleged front of authority for the majority view is that 28 U.S.C. § 959(b) was intended to establish a balanced playing field between debtors and non-debtors. ${ }^{355}$ Instead of retaining preemption as the lens for evaluating Estate Representative's' actions, ${ }^{356}$ courts pivoted to focusing on competition. Non-coincidentally, competition is a concern only facially present when an Estate Representative is operating a debtor's business. ${ }^{357}$ As one court put it, "[b]ankruptcy does not grant the debtor a license to eliminate the marginal cost generated by compliance with valid state laws that constrain nonbankrupt competitors." ${ }^{358}$ The district court in the Chrysler cases $^{359}$ similarly observed that "[w]here the business has ceased to operate, there is no risk that the debtor will gain an unfair advantage over its competition through its bankruptcy proceedings. ${ }^{360}$ With no legislative history for support, this perspective appears to be blatant ex post-revisionism - a manufactured policy basis to support restricting the scope of 28 U.S.C. $\S$ 959(b). Cases decided soon after Midlantic created momentum that led later courts to simply recite one or more of the abovelisted arguments with little or no new analysis. ${ }^{361}$

\footnotetext{
$352 \quad I d$.

353 The Supreme Court's interpretation of "conducting business" as including liquidations in 28 U.S.C. $\$ 960$ in California State Board of Equalization v. Sierra Summit, Inc., 490 U.S. 844, 852 (1989), casts doubt on this definition of "carrying on business."

354 Walker v. Maury Cnty. (In re Scott Hous. Sys., Inc.), 91 B.R. 190, 195 (Bankr. S.D. Ga. 1988).

355 In re Old Carco L.L.C., No. 09-50002 AJG, 2010 WL 4455648, at *7 (S.D.N.Y. Nov. 2, 2010); In re White Crane Trading Co., Inc., 170 B.R. 694, 702 (Bankr. E.D. Cal. 1994).

356 Gillis v. California, 293 U.S. 62, 66 (1934).

357 In re White Crane Trading Co., Inc., 170 B.R. at 702; In re Stable Mews Assocs., Inc., 41 B.R. 594, 600 (Bankr. S.D.N.Y. 1984).

358 In re White Crane Trading Co., Inc., 170 B.R. at 702; see Chicago v. Marshall, 281 F. Supp. 3d 702, 709 (N.D. Ill. 2017), rev'd on other grounds by In re Steenes, 942 F.3d 834 (7th Cir. 2019); In re Old Carco L.L.C., 2010 WL 4455648, at *7.

359 In re Old Carco L.L.C., 2010 WL 4455648.

$360 \quad I d$. at $* 7$.

361 E.g., SEC v. Wealth Mgmt. L.L.C., 628 F.3d 323, 334 (7th Cir. 2010); In re N.P. Mining Co., Inc., 963 F.2d 1449, 1461 (11th Cir. 1992); United States v. Zabka, 900 F. Supp. 2d 864, 868 (C.D. Ill. 2012); In re Gardens Reg'l Hosp. \& Med. Ctr., Inc., 567 B.R. 820, 829 (Bankr. C.D. Cal. 2017); In re St. Lawrence Corp., 239 B.R. 720, 726 (Bankr. D.N.J. 1999); In re Valley Steel Prod. Co., Inc., 157 B.R. 442, 448 (Bankr. E.D. Mo. 1993). The holding in Sec. Exch. Comm'n v. Wealth Mgmt. L.L.C. is notable because the result was correct, even though it was based on erroneous and
} 


\section{The Minority View Is Built on (More) Solid Foundations}

Whether it is the plain language of 28 U.S.C. $§ 959(b)$, the difficult linedrawing between liquidations and operations, or the distinction's incentivization of gamesmanship, the "minority view" that no distinction should exist between liquidating and operating Estate Representatives rests on more solid footing than the majority approach. The Supreme Court's most recent pronouncement regarding 28 U.S.C. $\S 959$ (b) only confirms the minority's superiority.

The use of two requirements - manage and operate - signals that Congress did not want to only require Estate Representatives' satisfaction of state law when operating property. Courts construe language in order to give effect to all provisions "so that no part will be inoperative or superfluous, void or insignificant." ${ }^{362}$ In considering the two terms manage and operate, courts should interpret them as having different meanings in order to evade making either term superfluous. The difference between manage (handling or directing property) compared to operate (causing the property to function) reflects the differences between the two terms and leaves neither as surplusage. ${ }^{363}$ The use of the two different terms reveals Congress's intent to require Estate Representatives to satisfy state laws not only when operating the debtor's property but also when handling or directing it. In reality, the use of two terms covers both liquidating and operating Estate Representatives.

The Supreme Court's recent declaration in Mission Products Holdings, Inc. v. Tempnology, L.L.C. ${ }^{364}$ further supports the distinction between management and operation. Recall, the Supreme Court explained that although 11 U.S.C. $\S 365$ affords an Estate Representative the power to reject an executory contract, "[it] does not grant the debtor an exemption from all the burdens that generally applicable law-whether involving contracts or trademarks - imposes on property owners. See 28 U.S.C. $\S 959$ (b) (requiring a trustee to manage the estate in accordance with applicable law)." ${ }^{965}$ Notice, this quote does not simply use the term operate. It also refers to property owners, a description inclusive of

\footnotetext{
unnecessary reasoning. See 628 F.3d at 332. In that case, a group of investors was contesting a receiver's distribution scheme, which equitably subordinated investors who had redeemed their shares, thus transforming the shares into corporate debt and their status from equity holder to creditor. See id. The equitable subordination meant that all investors would be treated equally regardless of whether they redeemed their shares. See id. As noted in Section II.C., a receivership court can authorize exactly this type of equitable scheme of distribution among creditors and equity holders as part of its common law authority, irrespective of state law. See id. Because the federal common law would have governed rather than state law, the determination regarding the scope of 28 U.S.C. § 959(b) was unnecessary. See id.

362 E.g., Corley v. United States, 556 U.S. 303, 314 (2009).

363 See supra Part III for discussion of plain language meanings of these terms.

364139 S. Ct. 1652 (2019).

$365 I d$. at 1666 (emphasis added).
} 
both liquidating and operating Estate Representatives. The Supreme Court's latest consideration of 28 U.S.C. $\$ 959$ (b) further reinforces the minority view.

The property subject to 28 U.S.C. $§ 959$ (b) is defined as "property in [the Estate Representative's] possession." It is not defined by the role of the property in the business operation. This is significant because, in many cases, the restructuring of a debtor will contemplate shutting down certain business operations while continuing to operate others. Thus, classifying a case as wholly a liquidation or wholly a reorganization is often impossible. ${ }^{366}$ Retail store bankruptcy cases illustrate the difficulty of such line drawing. At first blush, some stores are closed while others remain open. Is the debtor operating or liquidating? By defining the Estate Representative's obligation under 28 U.S.C. $\S 959$ (b) by reference to "property in his possession," Congress recognized that categorizing "property" as operating or liquidating is a fool's errand in most insolvency proceedings; the terms are just too fluid. Instead, Congress limited the scope of 28 U.S.C. $§ 959$ (b) based on the Estate Representative's possession of property, not her actions in relation to it. Taking the analysis a step further, retail debtors often conduct "going out of business sales" during which the debtor acquires additional inventory for the purpose of enhancing the overall sale. ${ }^{367}$ Although such sales technically qualify as liquidations, business operations form an integral part of the process and certain inventory will continue to be replenished to help increase total sales and generate customer traffic. ${ }^{368}$

Another problematic and related side-effect of distinguishing between liquidating and operating Estate Representatives is the potential for gamesmanship. Estate Representatives may delay certain actions until the case has reached a "liquidating" phase and is no longer governed by 28 U.S.C. $\S 959$ (b). The Fifth Circuit's opinion in Texas v. Lowe (In re H.L.S. Energy Co.,

366 See Texas v. Lowe (In re H.L.S. Energy Co., Inc.), 151 F.3d 434, 436 (5th Cir. 1998) (describing the gradual process of a trustee shuttering debtors' operations); In re Circle K Corp., No. B-90-5052-PHX-GBN, 1991 WL 349900, at *12-13 (Bankr. D. Ariz. Apr. 5, 1991) (explaining the problem of applying the distinction to a case where the Estate Representative is both liquidating and operating).

367 See, e.g., Debtors' Motion for Entry of Interim and Final Orders (I) Authorizing the Debtors to Obtain Postpetition Financing, (II) Granting Liens and Providing Superpriority Administrative Expense Status, (III) Modifying the Automatic Stay, (IV) Scheduling a Final Hearing, and (V) Granting Related Relief (request for post-petition financing to augment inventory for closing sales), In re Payless Holdings, L.L.C., No. 19-40883 (Bankr. E.D. Mo. Feb. 18, 2019), Dkt. Entry No. 216; Debtors' Motion for Entry of an Order (I) Authorizing the Sale of the Debtors' Optical Business, (II) Authorizing the Assumption and Assignment of Certain Executory Contracts And Unexpired Leases, (III) Authorizing a Settlement of Claims and Causes of Action, (IV) Granting Relief Related to the Wind-Down of The Debtors' Remaining Operations, and (V) Granting Related Relief, In re Specialty Shops Retail Holding Corp., No. 19-80064 (Bankr. D. Neb. Apr. 10, 2019), Dkt. Entry No. 1020.

368 Although such sales fit within 11 U.S.C. $\S 363(\mathrm{~b})$ rather than ordinary course operations covered by 28 U.S.C. $§ 959$ (b), see supra note 311 and accompanying text, it provides a helpful illustration of the fluidity between operations and liquidations. 
Inc. $)^{369}$ provides a paradigmatic example. There, a chapter 11 trustee operated a debtor post-petition, and after he sold the debtor's valuable assets, he converted the case to chapter $7 .^{370}$ During the chapter 11 case, Texas regulators attempted to enforce state laws requiring the plugging of unproductive oil wells. After conversion, the regulators eventually plugged the wells to satisfy the debtor's statutory obligations and filed requests for administrative expenses against the debtor's estate based on the cost of plugging. ${ }^{371}$ The Fifth Circuit did not allow the chapter 7 trustee to evade these claims. ${ }^{372}$ The debtor's estate remained subject to state laws requiring the plugging of unproductive wells irrespective of the trustee's status as a liquidating trustee. ${ }^{373}$ If the Fifth Circuit had applied the majority rule, the trustee would have dodged his obligations simply by virtue of an artificial divide. H.L.S. Energy illustrates how the majority rule promotes gamesmanship by Estate Representatives who are incentivized to delay any actions that would trigger 28 U.S.C. $\S 959$ (b) until the liquidating phase of a case commences. ${ }^{374}$

\section{E. The Definition of Insanity}

It is often said that doing the same thing over and over again but expecting a different result is the definition of insanity. ${ }^{375}$ In an era of electronic legal research, case law development should not repeat the same mistake. Yet, the most damning critique of the majority view is that it echoes a distinction that was already rejected by the Supreme Court in the parallel issue of Estate Representatives' liability for state taxes under 28 U.S.C. $§ 960$ (a).

Compared to 28 U.S.C. $§ 959(b), 28$ U.S.C. $\S 960($ a) serves a similar, but more limited, purpose. Section 960(a) provides that "any officers and agents conducting any business under authority of a United States Court" are subject to all applicable federal, state, and local taxes. ${ }^{376}$ Only when a federal statute grants

\footnotetext{
$369 \quad 151$ F.3d 434 (5th Cir. 1998).

$370 \quad$ Id. at 436.

$371 \quad$ Id.

$372 \quad$ Id. at 439.

$373 \quad$ Id. at 438.

$374 \quad$ See id. at 434.

375 Although a version of this saying has been attributed to Albert Einstein, the earliest verified use is in an Alcoholics Anonymous (AA) pamphlet. JAMES G. JENSON, STEP 2: A Promise OF Hope $10(1980)$

376 Like 28 U.S.C. $\S 959$ (b), 28 U.S.C. $\$ 960$ is also a specific saving statute that exempts state and local taxes from obstacle preemption. See supra Section IV.A; $c f$. Boteler v. Ingels, 308 U.S. 57, 61 (1939) (stating that the enactment of the predecessor of 28 U.S.C. § 960 "indicate[d] a Congressional purpose to facilitate — not to obstruct — enforcement of state laws.").
} 
officers or agents immunity will the state or local tax be preempted ${ }^{377}$-i.e. when a direct conflict exists. ${ }^{378}$ The similarities do not end there. Prior to the Supreme Court's holding in California Equalization Board v. Sierra Summit, Inc., ${ }^{379}$ courts were split on whether liquidating trustees were required to comply with 28 U.S.C. $\S 960$ and pay state taxes. ${ }^{380}$

The genesis of the distinction was two separate opinions from the Ninth Circuit arising from the same bankruptcy case. In California State Board of Equalization v. Goggin, ${ }^{381}$ the Ninth Circuit held that a bankruptcy trustee was not subject to California sales taxes when he was liquidating the debtor's estate. The court's holding hinged upon the applicable state law and California courts' interpretation that the relevant state tax statute did not apply to business liquidations. ${ }^{382}$ Later, California sued to recover the taxes from both the trustee personally as well as the purchasers of the goods ("Goggin II"). The court reiterated its conclusion ${ }^{383}$ but added further reasoning that the tax was an impermissible burden on the liquidation and administration of the estate. ${ }^{384}$ Later courts relied upon Goggin II to distinguish between liquidating versus operating representatives, without considering the underlying state law. ${ }^{385}$ Echoing the assertions of the majority interpretation of 28 U.S.C. $\S 959(\mathrm{~b})$, the same arguments (both statutory and public policy) were mustered to except liquidating trustees from paying applicable taxes under 28 U.S.C. $§ 960(a) .{ }^{386}$ The statutory language argument was based on the allegation that liquidating trustees were not

\footnotetext{
377 Bezanson v. Maine (In re Warmings A.G. Food Ctr.), 50 B.R. 748, 752 (D. Me. 1985) (" $[\mathrm{P}]$ roperty of an estate in bankruptcy is subject to all state and local taxes absent a clearly expressed congressional intent to the contrary.").

378 As a result, 28 U.S.C. $§ 960$ (a) is also correctly categorized as a specific saving clause.

379490 U.S. 844 (1989).

380 Compare Great Am. Bank of Broward Cnty. v. McCracken (In re Cusato Bros. Int'l, Inc.), 750 F.2d 887, 891 (11th Cir. 1985) (exempting liquidating trustee), Cal. State Bd. of Equalization v. Goggin, 245 F.2d 44 (9th Cir. 1957), cert. denied, 353 U.S. 961 (1957) (same), and In re Samoset Assocs., 14 B.R. 408, 414 (Bankr. D. Me. 1981) (same), with Blackmon v. Nichols (In re Hatfield Const. Co.), 494 F.2d 1179, 1181 (5th Cir. 1974) (liquidating trustee must pay applicable taxes), and Missouri v. Gleick, 135 F.2d 134, 137 (8th Cir. 1943) (same).

$381 \quad 191$ F.2d 726, 728 (9th Cir. 1951) [hereinafter Goggin I].

382 Goggin I, 191 F.2d at 729-30 (relying upon Cal. State Bd. of Equalization v. Boteler, 131 F.2d 386, 388 (9th Cir. 1942)).

383 Cal. State Bd. of Equalization v. Goggin, 245 F.2d 44 (9th Cir. 1957), cert. denied, 353 U.S. 961 (1957) [hereinafter Goggin II].

384 Goggin II, 245 F.2d at 46. The Ninth Circuit also relied upon the intergovernmental tax immunity doctrine. Id. at 47.

385 Catlin v. Me. Dep't of Tax'n (In re Sheldon's Inc. of Me.), 28 B.R. 568, 571 (Bankr. D. Me. 1983); Babb v. Oklahoma (In re Rhea), 17 B.R. 789, 791 (Bankr. W.D. Okla. 1982); In re Supergrate Open Steel Flooring Co., 1 B.R. 660, 664 (Bankr. C.D. Cal. 1979).

386 E.g., Great Am. Bank of Broward Cnty. v. McCracken (In re Cusato Bros. Int'1, Inc.), 750 F.2d 887, 891 (11th Cir. 1985); In re Samoset Assocs., 14 B.R. 408, 414 (Bankr. D. Me. 1981).
} 
"conducting any business." $" 387$ The policy arguments against imposing state taxes on liquidating trustees were that it (i) "would be an impermissible burden upon the liquidation process" $" 388$ and (ii) would not further the goal of ensuring Estate Representatives compete on an equal playing field with those who are not subject to federal insolvency laws. ${ }^{389}$ Recall, these are the exact same arguments that are currently accepted to bifurcate treatment of liquidating and operating Estate Representatives under 28 U.S.C. § 959(b).

Other courts were unpersuaded by these arguments. ${ }^{390}$ They determined that the language of 28 U.S.C. $\S 960$ (a) (and its predecessor) was not a clear articulation of an exemption for liquidating representatives from applicable taxes and such taxes were not an impermissible burden on the liquidating duties of the representatives. ${ }^{391}$ Indeed, absent a clear indication by Congress, liquidating representatives who received the same protections provided by states and municipalities also remained subject to the same burdens. ${ }^{392}$

In California State Board of Equalization v. Sierra Summit, Inc., the Supreme Court resolved the circuit split and refused to recognize an exception for liquidating representatives to 28 U.S.C. $\S 960$ (a) ${ }^{393}$ In the process, the Court considered and rejected both the plain language and policy bases. ${ }^{394}$ The Court emphasized that only a clear indication from Congress could exempt a liquidating representative from state taxes. ${ }^{395}$ Ironically (at least from the perspective of this Article), the Supreme Court relied upon Palmer as confirmation that property held by a trustee is subject to state and municipal taxes, just as it would have been in the hands of a non-debtor owner. ${ }^{396}$ The term "conducting any business" - exactly the term used in Palmer-did not sufficiently indicate an exception for liquidating representatives to 28 U.S.C. $\S 960$ (a). "If Congress had wished to declare otherwise, its intent would have to

\footnotetext{
387 Great Am. Bank of Broward Cnty., 750 F.2d at 890 (citing, inter alia, In re Samoset Assocs., 14 B.R. at 414); In re F. P. Newport Corp., 144 F. Supp. 507, 509 (S.D. Cal. 1956).

388 Great Am. Bank of Broward Cnty., 750 F.2d at 890 (examining Goggin II).

389 In re N.Y., New Haven, \& Hartford R.R. Co., 360 F. Supp. 1155, 1158 (D. Conn. 1973); In re Samoset Assocs., 14 B.R. at 414; see O’Neill v. United States, No. 72-00010/11(C), 1980 WL 1767, at*6 (W.D. Va. Oct. 24, 1980), rev'd sub nom. on other grounds, Williams v. United States, 667 F.2d 1108 (4th Cir. 1981).

390 Blackmon v. Nichols (In re Hatfield Const. Co.), 494 F.2d 1179, 1181 (5th Cir. 1974); Missouri v. Gleick, 135 F.2d 134, 137 (8th Cir. 1943).

391 Blackmon, 494 F.2d at 1181; Gleick, 135 F.2d at 137.

392 Hoffman v. R \& E Builders, Inc. (In re Woodland Builders, Inc.), 87 B.R. 774, 777 (Bankr. D. Conn. 1988) (quoting Swarts v. Hammer, 194 U.S. 441, 444 (1904)).

393490 U.S. 844, 852 (1989).

$394 \quad$ Id. at 853.

395 Id. at $851-52$. The Court also reject the intergovernmental tax immunity doctrine as a relic of the past. $I d$. at $848-50$.

$396 \quad$ Id. at 852.
} 
be 'clearly expressed, not left to be collected or inferred from disputable consideration of convenience in administering the estate of the bankrupt." ${ }^{397}$ In dismissing the policy argument, the Court relied upon earlier statements supporting the broad application of state law to property in the hands of representatives, stating, "by the transfer to the [representative] no mysterious or peculiar ownership or qualities are given to the property, and that there is nothing in that to withdraw it from the necessity of protection by the State and municipality, or which should exempt it from its obligations to either." ${ }^{\prime 398}$

The parallels between 28 U.S.C. $\$ 959$ (b) and 28 U.S.C. $§ 960$ (a) and the Supreme Court's application of 28 U.S.C. $\S$ 960(a) to liquidating representatives in Sierra Summit should guide the interpretation of "manage and operate property." Regulating the management and operation of property within a state is a traditional state function, and as a result, Congressional intent to preempt such state laws must be "clear and manifest." 399 Just like the term "conducting any business" in 28 U.S.C. $§ 960$ or as used in Palmer (the genesis for the distinction), "manage and operate property" is not a clear indication that Congress wanted to except liquidating Estate Representatives from satisfying relevant state law. Moreover, the possession by the Estate Representative does not eliminate the Estate Representative's duty to follow state law as nothing mysterious or peculiar occurs - the Estate Representative merely accedes to possession from the debtor. Clear Congressional expression is required, but none exists.

\section{CONCLUSION}

Much ink has been spilled bemoaning the failure of Congress to update federal insolvency law (especially bankruptcy) to reflect modern finance and legal practice. ${ }^{400}$ The lack of framework for evaluating conflict preemption in insolvency proceedings is not an issue that will be solved by legislation and lobbying. It is inherent to the relationship between state substantive law and federal insolvency law. Only the efforts of practitioners, judges, and academics can produce a suitable structure that will alleviate the uncertainty currently

\footnotetext{
397 Id. at 854 (quoting Swarts, 194 U.S. at 444).

398 Id. at 853-54 (quoting Swarts, 194 U.S. at 441).

399 Cf. BFP v. Resol. Tr. Corp., 511 U.S. 531, 544 (1994) (quoting English v. Gen. Elec. Co., 496 U.S. 72,79 (1990)).

400 See, e.g., Lynn M. LoPucki, The Trouble with Chapter 11, 1993 Wis. L. REv. 729 (1993); Harvey R. Miller, Chapter 11 in Transition-from Boom to Bust and into the Future, 81 AM. BANKR. L.J. 375 (2007); Stephen W. Rhodes, Eight Statutory Causes of Delay and Expense in Chapter 11 Bankruptcy Cases, 67 Am. BANKR. L.J. 287 (1993); Charles J. Tabb, What's Wrong with Chapter 11? (University of Illinois College of Law, Legal Studies Research Paper No. 19-15, 2019).
} 
plaguing conflict preemption. The test advocated by this Article is the first (and long overdue) word on this important subject.

Although certain aspects of the proposed test are outcome determinative (most notably, the application of the test to both liquidating and operating Estate Representatives), the test's primary contribution is its significant improvement on current process employed by courts to evaluate conflict preemption in federal insolvency proceedings. Consider the faulty ignition switch claims in the General Motors bankruptcy case. Does the sale of GM's assets eliminate state-law successor liability? ${ }^{401}$ The creditors of GM benefit from a higher sale price if the sale extinguishes the claims, but it would violate applicable state law.

The worker retention ordinances enacted in response to the COVID-19 pandemic present a timelier example. ${ }^{402}$ They require that a purchaser give hiring priority to the seller's workers. ${ }^{403}$ Must a bankruptcy purchaser follow the ordinance notwithstanding the potential conflict between the ordinance and the authorization to sell property free and clear of claims and interests under federal insolvency law? It would prove too much to claim that the proposed test will provide easy answers to thorny conflict preemption issues like whether state law successor claims survive a sale free and clear of liens and interests. ${ }^{404}$ The proposed test, however, provides a framework for evaluating the relationship that conforms the three primary sources of authority for preemption; a dramatic change from relying upon squishy general principles. ${ }^{405}$

\footnotetext{
401 The Second Circuit would have answered in the affirmative, if the due process rights of the ignition switch claimants had been vindicated. See Elliot v. Gen. Motors L.L.C. (In re Motors Liquidation Co.), 829 F.3d 135, 156-58 (2d Cir. 2016).

402 John G. Yslas \& Phillip J. Ebsworth, Is a Purchase in Bankruptcy Really Free and Clear of Liability During COVID-19?, SEYFARTH SHAW L.L.P (June 1, 2020), https://www.wagehourlitigation.com/uncategorized/is-a-purchase-in-bankruptcy-really-free-andclear-of-liability-during-covid-19/ (citing L.A., CAL., MuniCIPAL CODE art. 4-72J-B (2020)).

403 See L.A., CAL., Municipal Code art. 4-72J-B (2020).

404 See, e.g., Rachel P. Corcoran, Why Successor Liability Claims Are Not "Interests in Property” Under Section 363(f), 18 Am. BAnKR. InSt. L. REV. 697, 747 (2010); Swett III, supra note 316; accord Callidus Cap. Corp. v. Harvey Indus. L.L.C., No. 2015-cv-10616-RHC-EAS, 2015 WL 4940123, at*5 (E.D. Mich. Aug. 18, 2015) (considering a receivership sale eliminating successor liability without evaluating the preemption issue created by 28 U.S.C. § 959(b)).

405 Baker \& Drake, Inc. v. Public Serv. Comm'n of Nev. (In re Baker \& Drake, Inc.), 35 F.3d 1348, 1353 (9th Cir. 1994); Pub. Serv. Co. of N.H. v. New Hampshire (In re Pub. Serv. Co. of N.H.), 108 B.R. 854, 869 (Bankr. D.N.H. 1989); see also In re Am. Suzuki Motor Corp., 494 B.R. 466, 477 (Bankr. C.D. Cal. 2013).
} 